
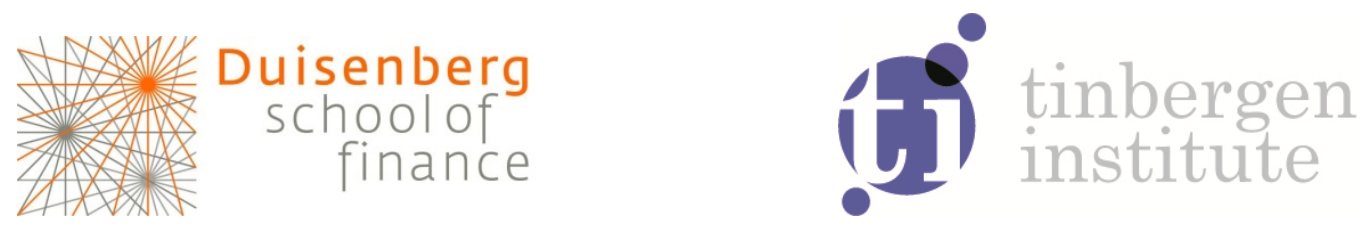

Duisenberg school of finance - Tinbergen Institute Discussion Paper

TI 14-079/IV/DSF76

\title{
Mutual Funds and Information Diffusion: \\ The Role of Country-Level Governance
}

Chunmei Lin'

Massimo Massa ${ }^{2}$

Hong Zhang ${ }^{2,3}$

1 Erasmus School of Economics, Erasmus University Rotterdam, and Tinbergen Institute, the Netherlands;

2 INSEAD, France;

3 Tsinghua University, Singapore. 
Tinbergen Institute is the graduate school and research institute in economics of Erasmus University Rotterdam, the University of Amsterdam and VU University Amsterdam.

More TI discussion papers can be downloaded at http://www.tinbergen.nl

Tinbergen Institute has two locations:

Tinbergen Institute Amsterdam

Gustav Mahlerplein 117

1082 MS Amsterdam

The Netherlands

Tel.: +31(0)205251600

Tinbergen Institute Rotterdam

Burg. Oudlaan 50

3062 PA Rotterdam

The Netherlands

Tel.: +31(0)10 4088900

Fax: +31(0)104089031

Duisenberg school of finance is a collaboration of the Dutch financial sector and universities, with the ambition to support innovative research and offer top quality academic education in core areas of finance.

DSF research papers can be downloaded at: http://www.dsf.nl/

Duisenberg school of finance

Gustav Mahlerplein 117

1082 MS Amsterdam

The Netherlands

Tel.: +31(0)20 5258579 


\title{
Mutual Funds and Information Diffusion: The Role of Country-Level Governance
}

\author{
Chunmei Lin*, Massimo Massa ${ }^{\dagger}$, Hong Zhang ${ }^{\ddagger}$
}

\begin{abstract}
We hypothesize that poor country-level governance, which makes public information less reliable, induces fund managers to increase their use of semi-public information. Utilizing data from international mutual funds and stocks over the 2000-2009 period, we find that semi-public information-related stock rebalancing can be five times higher in countries with the worst quality of governance than in countries with the best. The use of semi-public information increases price informativeness but also increases information asymmetry and reduces stock liquidity. It also intensifies the price impact and liquidity crunch during the recent global financial crisis.
\end{abstract}

\footnotetext{
*Erasmus University Rotterdam and Tinbergen Institute, Postbus 1738, 3000 DR, Rotterdam, Netherlands, E-mail: lin@ese.eur.nl

${ }^{\dagger}$ INSEAD, Boulevard de Constance, 77305 Fontainebleau Cedex, France, E-mail: massimo.massa@insead.edu

$\$$ INSEAD and PBC School of Finance at Tsinghua University, 1 Ayer Rajah Avenue, Singapore, 138676, Email: hong.zhang@insead.edu

We thank Alexandar Andonov, John Griffin, Dong Wook Lee, Jerry Parwada, Mathew Spiegel and participants at the 24th Australasian Finance \& Banking conference, the 2012 China International Conference in Finance, the 2014 EMG-ECB Emerging Markets Finance Conference, and BI Norwegian Business School for helpful comments. We are also grateful to two anonymous referees and the editor, Andrew Karolyi, for many insightful comments and detailed suggestions. Previous versions of the paper had been circulated under the name "Stock Market Fragility and the Quality of Governance of the Country".
} 


\section{Introduction}

The recent financial crisis has shifted the role of institutions to the forefront of analysis. It has been shown that the quality of country-level governance affects corporate governance and, thus, firm value (Doidge et al., 2004, 2007, Aggarwal et al., 2009). Less attention has been focused on how countrylevel governance affects how investors process information. This economic channel, however, may affect information transmission in the financial markets. Let us consider the Kim and Verrecchia (1994) intuition that savvy market participants, such as asset managers and analysts, can process information better than the market by converting a firm's noisy public signals (e.g., earnings announcements) into more accurate information (semi-public information). ${ }^{1}$ In this context, follow-up trading by such savvy market participants has a dual impact on the market: on the one hand, it contributes to price efficiency by impounding new information into the stock price; on the other hand, it reduces stock liquidity by increasing information asymmetry and therefore discouraging the participation of less capable investors (those unable to process information).

We argue that the quality of country governance affects this information-generating process. Public information is typically of lower quality in countries with poor governance: firms' publicly released financial reports are less accurate (DeFond et al., 2007), firms are less transparent (Morck et al., 2000, Jin and Myers, 2006, Haw et al. 2012, Bartram et al., 2012), and firm behavior may be distorted by the threat of expropriation by the State (e.g., Opp, 2012). For example, in Oct 2008, the People's Daily in China — the country with the worst protection of property rights-reported: "Local politicians suppressed a company report about tainted milk powder until the completion of the Olympic Games to avoid creating a negative influence on society." In this context, the absence of reliable public information incentivizes savvy market participants to generate more semi-public information than they do in countries with good governance. Their ensuing trading, consequently, both increases the (otherwise low) informativeness of stock prices and reduces stock market liquidity.

\footnotetext{
${ }^{1}$ The notion that some investors are better than others at processing public information has important economic implications, as noted by Kandel and Pearson (1995). More recently, Engelberg, Reed and Ringgenberg (2012) show that a significant portion of short sellers' profitability actually comes from their skills in analyzing public information.
} 
Thus, our main intuition, which we call the information asymmetry augmentation hypothesis, assigns a fundamental role to (poor) country governance in shaping financial markets because its (negative) impact on public information cannot be offset without hurting other properties of the market. Specifically, the improvement in price informativeness comes at the price of increased information asymmetry (among different types of investors) and ensuing reduced stock liquidity.

We can compare this intuition with an alternative information asymmetry reduction hypothesis that focuses on the information asymmetry between the firm and the market - as opposed to that between more- and less-savvy market participants from the previous hypothesis. Because the pursuit of semi-public information by savvy investors helps reduce such asymmetry, it encourages participation and increase liquidity, helping to reduce the negative impact of poor country governance with no further negative implications on the stock market.

We test these hypotheses using data on international mutual fund managers - our proxy for savvy investors - and international stocks over the 2000-2009 period. We follow Acemoglu and Johnson (2005) and focus on two representative types of country-level governance (henceforth, governance): one that supports private contracts, i.e., contracting institutions (horizontal governance), and one that constrains governments and expropriation by the elite, i.e., property rights institutions (vertical governance). Each type of governance affects the diffusion of information throughout the market. For instance, the threat of expropriation is a major motivation for firms to hide information (e.g., Morck et al., 2000, Jin and Myers, 2006). Property rights institutions are also known to be linked to firm value (Doidge et al., 2004, 2007). Contracting institutions, on the other hand, directly affect the boundary and complexity of firms (e.g., Williamson 1975, 1985, Acemoglu et al., 2009), and it is well known that public information for more complex firms is less accurate (e.g., Cohen and Lou, 2012).

Relying on Kim and Verrecchia (1994) and on the accumulated empirical evidence indicating that analysts are able to process information, particularly in the global market (e.g., Chang et al., 2001, Jin and Myers, 2006, Bae et al., 2008, Xu et al., 2013), we use changes in analyst recommendations as a proxy for semi-public information. We further proxy for the use of semi-public information of a fund with the sensitivity of its semi-annual changes in stock holdings to the contemporaneous changes in 
analyst recommendations for a specific stock. We find strong evidence that this sensitivity is affected by governance: whereas a one-standard-deviation increase in analyst recommendations typically induces funds to increase their stock holdings by $1.03 \%$ and $6.23 \%$ for stocks in countries with the best horizontal and vertical governance, respectively. The effect in countries with the worst governance is $17.2 \%$ and $17.8 \%$, or five times higher, which suggests that mutual fund managers use more semi-public information in countries with poor governance.

To validate managers' incentives in pursuing semi-public information, we examine how fund managers use semi-public information side-by-side with pure (i.e., unprocessed) public information and how this use of information affects fund performance. We use Dow Jones news releases as a proxy for pure public information because they typically contain less professional judgments than analyst reports. We first verify that there is a negative (positive) correlation between fund managers' use of semi (pure) public information and the quality of country governance. More importantly, relying on semi-public information enhances risk-adjusted performance. A one-standard-deviation increase in the use of semi-public information induced by poor horizontal (vertical) governance is related to a higher annual risk adjusted performance of 38 (39) basis points. By contrast, relying on pure public information does not lead to superior performance. This test confirms both the usefulness of our empirical proxy of semi-public information and the benefits for funds to pursue semi-public information when country governance is poor.

Building on these findings, we further investigate how governance impacts liquidity and stock price informativeness by affecting the use of semi-public information. Empirically, a one-standarddeviation increase in the use of semi-public information due to poor horizontal (vertical) governance is related to an $11 \%(15 \%)$ higher Amihud illiquidity, a 3.4\% (2.9\%) higher portion of zero daily returns, and a $2.5 \%(2.2 \%)$ higher log of idiosyncratic volatility. Therefore, poor governance-induced usage of information increases illiquidity and stock informativeness as per Morck et al. (2000) and Jin and Myers (2006), which is consistent with the information asymmetry augmentation hypothesis. 
One caveat here is that idiosyncratic volatility may not be a clean proxy for informativeness. ${ }^{2}$ To further verify the conclusion about stock informativeness, we examine price responses to news and find that the use of semi-public information amplifies the stock reaction to news - i.e., stock returns experience a greater positive (negative) reaction to good (bad) news. This pattern confirms that price informativeness increases with the use of semi-public information. Importantly, we also find that the poor-governance induced use of semi-public information is typically related to stocks with lower valuations, such as a lower market-to-book ratio or Tobin's Q, suggesting that the cost of increased information asymmetry outweighs the benefit of improved informativeness.

Information processing also has important implications during crises. The information asymmetry augmentation hypothesis posits that when markets with poor governance are exposed to a major negative shock - a crisis - semi-public information-related trades will further discourage liquidity trading, leading to price drops and liquidity crunches that far exceed those experienced by stocks in countries with strong institutions. Through this channel, markets with poorer country governance are essentially more vulnerable to crises. By contrast, according to the information asymmetry reduction hypothesis, semi-public information-related trades stabilize the market during the crisis. Our tests during the 2008-2009 global financial crisis lend strong support to the former hypothesis. The impact on liquidity is particularly significant and more substantial than that observed during normal periods: a one-standard-deviation increase in the (pre-crisis) fund use of semi-public information induced by poor horizontal and vertical governance is associated with a $31 \%$ and $27 \%$ higher Amihud illiquidity for any given stock during the crisis period, respectively.

Finally, we address potential endogeneity issues and provide a list of robustness checks. Among them, we show that the use of alternative governance indices - e.g., disclosure (Bushman et al., 2004), the poor governance Index (computed from Karolyi et al., 2012), anti-self-dealing (Djankov et al., 2008), and accounting transparency (Durnev et al., 2009) - lead to similar results. We also find that short-selling constraints enhance the impact of governance-induced usage of information during the crisis.

\footnotetext{
${ }^{2}$ Idiosyncratic risk may be affected by country risk, investor protection, financial developments and openness, disclosure and noise trading, and growth opportunities. Bartram et al. (2012) provide a detailed summary and additional references.
} 
Overall, our analysis demonstrates how country governance affects the way information is processed and incorporated into stock markets. Differential processing of information (e.g., Kim and Verrecchia 1994) is known to affect information asymmetry and market conditions following the announcement of macro news (Green, 2004) and corporate news (e.g., Lee et al., 1993, Krinsky and Lee 1996, Madureira and Underwood 2008, Sarkar and Schwartz 2009). Its impact may even be extended to the effectiveness of regulations (Bailey et al., 2003). Our unique contribution is to highlight the pivotal role played by fund managers who can generate semi-public information when public information is less reliable because of poor governance. However, poor country-level governance proposes a fundamental challenge to the financial market even in the presence of informed managers: the low-information problem of poor country governance can be solved only by creating other problems, such as illiquidity, which may outweigh the positive effects of more information and destabilize the market during crises.

This intuition not only enriches the literature examining the role of country-level governance on financial markets (e.g., Demirguc-Kunt and Maksimovic, 1999, Wurgler, 2000, Morck et al., 2000, Jin and Myers, 2006, Bartram et al., 2012, Karolyi et al., 2012, Opp 2012) but also has important normative implications. Our results suggest that, for countries with poor governance, advances in institutions in either property rights or contracting quality are a necessary condition to further improve their financial markets. Without a proper progress in institutions, policies focusing solely on the development of financial intermediaries such as mutual funds may adversely affect the market. Overall, country-level governance seems to shape the market in a more profound way than traditionally understood by affecting the creation and transfer of semi-public information.

Griffin et al. (2011) show that insider trading reduces the price reaction to the release of public information. Our results are complementary in that we focus on one type of savvy external investors who can process information: mutual funds. Unlike insiders, whose trading injects information into the market prior to the release of public news (e.g., Kyle 1985), mutual funds process public information during the news release period and, therefore, enhance price informativeness over the period. 
We also contribute to several other strands of the literature. We are the first to show how countrylevel governance affects asset pricing by impacting mutual funds' learning processes and information discovery in the international context. In so doing, we contribute to the literature regarding how country-level governance affects mutual funds' global investments (e.g., Chan et al., 2005, Ferreira and Matos, 2008) and to the literature on the impact of country-level governance on firms (e.g., Doidge et al., 2004, 2007, Aggarwal et al. 2009). In addition, we extend the literature on the use of information by mutual funds (e.g., Kacperczyk and Seru, 2007) to the international context. We show that the information content of mutual fund trading and its market implications may be different in weak governance countries compared with the U.S.

II. Testable Hypotheses and Empirica 


\section{Specifications}

We now lay out our hypotheses. We provide the main intuition here and report the model in detail in Appendix A. The key assumption of both our model and that of Kim and Verrecchia (1994) is that a noisy public signal released by a firm (e.g., an earnings announcement) can be better processed by certain market participants who are able to use their informed judgment to gain an informational advantage over the market. Indeed, experts who follow a firm closely (e.g., financial traders and analysts) are capable of making informed judgments about the public signal that allow them to improve its precision. We refer to the superior information coming from informed judgments or better skills at processing public information as semi-public information to differentiate it from the truly private information that corporate insiders may directly observe.

The incentive to generate semi-public information is stronger when public information is less reliable and uncertainty is higher-i.e., when the public information in the market is noisier. We argue that this is the case for firms located in countries with poor country-level governance because the risk of expropriation makes the cash flows of these firms riskier (e.g., Opp, 2012) and makes it more advantageous (if not easier) for these firms to hide information (Morck et al., 2000, Jin and Myers, 2006, De Fond et al., 2007, Haw et al. 2012, Bartram et al., 2012). In addition, firms invest less in corporate governance in countries with poor institutions (Doidge et al., 2007). These effects reduce the quality of firm disclosure and make public information less trustable, which effectively incentivizes institutional investors to use more semi-public information and less public information in their trading. Thus, the incentive to generate semi-public information is stronger when the quality of country-level governance is lower.

In Kim and Verrecchia (1994), the use of semi-public information allows professional investors (fund managers) to generate superior performance. This intuition also applies internationally: poor governance-induced use of semi-public (public) information leads (does not lead) to better riskadjusted performance. The link to performance not only completes the logic of the argumentsuperior performance gives funds an incentive to pursue semi-public information-but also helps us empirically differentiate and validate the proxies we use for semi-public and public information. 
The impact of country-level governance on fund managers' behavior has implications for the financial market. In general, trading on semi-public information is not only profitable but also partially revealing (e.g., Kyle 1985) because it impounds information into the market, effectively ameliorating its informational efficiency. Meanwhile, however, the informational advantage enjoyed by the investors trading on semi-public information increases information asymmetry between these investors and other less-informed market participants, such as discretionary liquidity traders, which discourages the trading of such less-informed traders. In other words, the ability of some traders to process semipublic information will simultaneously increase stock price informativeness, enhance information asymmetry, and reduce liquidity. Poor country-level governance, by reducing the precision of public information and enhancing the incentive for fund managers to use semi-public information, strengthens these asset-pricing effects, which suggests that poor country-level governance can have an incremental impact on the informativeness and illiquidity of the assets in the market by inducing such behavior in fund managers. This hypothesis thus posits that the use of semi-public information induced by poor country-level governance improves the general informativeness of the stock price but reduces stock liquidity.

These considerations can be summarized as the information asymmetry augmentation hypothesis. This hypothesis is articulated in two parts. First, poor country-level governance induces capable fund managers to discover and use semi-public information. Second, the use of semi-public information induced by poor country-level governance improves the general informativeness of the stock price at the cost of lowered levels of liquidity.

An alternative hypothesis (the information asymmetry reduction hypothesis) posits that the pursuit of semi-public information increases stock informativeness and reduces the informational asymmetry between the firm and the rest of the market. Reducing this type of information asymmetry should increase the market participation of external investors and, therefore, stock liquidity. In this case, the activity of savvy investors can ameliorate the bad influence of poor country-level governance at no additional cost. Overall, this hypothesis posits that the use of semi-public information induced by poor 
country-level governance improves the general informativeness of the stock price and improves liquidity.

One corollary for both hypotheses concerns behavior during periods of major market shocks. The information asymmetry augmentation hypothesis posits that when markets with poor country-level governance are exposed to a major negative shock, such as a crisis, fund managers' trades will further discourage liquidity trading, leading to price drops and liquidity crunches that far exceed those experienced by stocks in countries with strong institutions. By contrast, the information asymmetry reduction hypothesis posits that when markets with poor governance are exposed to a major negative shock, fund managers' trades will increase liquidity trading, leading to lower price drops and better liquidity conditions. In other words, the corollary relates the quality of country-level governance to a market's vulnerability to crises.

\section{Data and Variable Construction}

We now describe the sources of our data and the construction of our main variables.

\section{A. Data Sample and Sources}

Our sample covers the $2000-2009$ period. We focus on open-end equity mutual funds. We obtain the data on international mutual funds from Morningstar International, which has complete coverage of open-end mutual funds worldwide beginning in the early 1990s. The database is survivorship bias-free and includes data on both active and defunct funds. The initial sample included 65,336 equity funds and share classes (both active and dead funds). Different share classes are reported for each fund. These represent claims to the same portfolio of assets, but with different fees. We consolidate multiple fund share classes into portfolios and focus on portfolio-level information. ${ }^{6}$ The ensuing sample contains 27,992 equity fund portfolios (both active and dead funds), which we will call funds.

\footnotetext{
${ }^{6}$ The primary fund is typically the class with the highest total net assets (TNA). In general, the primary class represents more than $80 \%$ of the total assets across all share classes.
} 
We match the funds with ownership data from FactSet/LionShares. This database provides portfolio holdings for institutional investors worldwide. ${ }^{7}$ We consider all types of stock holdings of open-end funds (common shares, ADR, GDR, and dual listings). The reporting frequencies of mutual fund holdings are quarterly (34\% of the cases), semi-annually (58\%), or annually (8\%). We choose the semi-annual frequency to include the majority of funds. We require that the funds are fully invested in equity (the total amount invested in equity should not be lower than $95 \%$ of the total net asset value) and international (the total amount of foreign equity must be more than $50 \%$ ). We also exclude funds that hold fewer than 10 foreign stocks. This threshold allows us to have a reasonable cross-section to estimate the fund-level use of semi-public information in different countries. ${ }^{8}$

In terms of assets, we start with all the publicly listed companies worldwide for which we have accounting and stock market information from Datastream/WorldScope and CRSP/Compustat. For each company, we consider only common stocks. This sample is then matched with data on institutional investors' stock holdings from FactSet/LionShares, information from analyst recommendations from $\mathrm{I} / \mathrm{B} / \mathrm{E} / \mathrm{S}$, and information on Dow Jones News reports contained in RavenPack (discussed below). ${ }^{9}$ We then manually merge Morningstar and FactSet/LionShares and match mutual fund holdings with Datastream/WorldScope and CRSP.

The starting sample from Datastream/WorldScope and CRSP covers 45,343 firms over the period. After the match with Factset/Lionshare and MorningStar, the sample is reduced to 23,045 firms over the period. We further require that stocks have analyst recommendations from $\mathrm{I} / \mathrm{B} / \mathrm{E} / \mathrm{S}$ and countrylevel governance information based on Acemoglu and Johnson (2005), which reduces the number of stocks to 21,329 . We also apply several screening procedures for Datastream data errors in monthly

\footnotetext{
${ }^{7}$ The database contains institutional holdings at the investor stock level in 73 countries, with positions totaling US\$18.29 trillion as of December 2008. FactSet/LionShares compiles institutional ownership from semi-public filings by investors (such as 13-F filings in the U.S.), company annual reports, stock exchanges, and regulatory agencies around the world. Institutions are defined as professional money managers, including mutual fund companies, pension funds, bank trusts, and insurance companies. Overall, institutional ownership represents over $40 \%$ of the total world stock market capitalization in our sample period. In our analyses, we focus on open-end mutual fund ownership, whereas we control for the general institutional ownership in our regressions.

${ }^{8}$ We generate consistent results by imposing a filter of $30 \%$ or $80 \%$ foreign assets. The results for these different samples are in the internet appendix. Although the foreign holdings requirement reduces the entire sample size, it increases the relative precision in proxying for the reliance of investors on semi-public information that is induced by country-level governance.

${ }^{9}$ We combine DataStream data with the institutional holdings data from FactSet using SEDOL codes (only for non-U.S. firms) and ISIN codes. We use CUSIP to merge institutional holdings data with U.S. security data from CRSP. We then match every stock holding in the fund portfolio with the respective analyst recommendation available from I/B/E/S.
} 
returns, as suggested by Ince and Porter (2006) and others, and drop penny stocks (stocks priced at less than $\$ 1 /$ share) and stocks with fewer than 12 months of returns or trading information.

Our final sample includes 12,300 mutual funds from 44 countries investing in 16,313 stocks in 50 countries. Most funds are from developed countries. Among these funds, U.S. funds represent $69 \%$ of the sample in terms of TNA but only $22 \%$ of the number of funds. A further discussion of the data will be provided when we examine the summary statistics.

\section{B. Information and Governance Proxies}

We use two proxies for information. To proxy for semi-public information, we use data on analyst recommendations. This choice follows Kim and Verrecchia (1994) and is supported by the empirical literature that shows that active financial analysts are able to process better information, particularly in the global markets (e.g., Chang et al., 2001, Jin and Myers 2006, Bae et al., 2008, Xu et al., 2013). In the same spirit, we use media reports as a proxy for pure public information because media reports typically involve less in-depth judgments, as we will discuss shortly. The original I/B/E/S database assigns 1 for 'strong buy' and 5 for 'strong sell'. To simplify the interpretation of our results, we

reverse the $\mathrm{I} / \mathrm{B} / \mathrm{E} / \mathrm{S}$ ranks by subtracting the raw rating from 6 . Thus, an increase in the analyst recommendation in our analysis is good news for the stock. To make the data homogenous across countries, we standardize the distribution of consensus recommendations with respect to each country by removing the country average and scaling the difference by the standard deviation of all concurrent recommendations in the country. Our results are robust if we do not scale the recommendations.

The proxy for public information is the Composite Sentiment Score (CSS), which is developed by RavenPack, a leading global news database that collects real time firm news from Dow Jones Newswires, regional editions of the Wall Street Journal, and Barron's. It begins in 2000 and covers more than 170,000 entities over 100 countries. RavenPack conducts linguistic analyses and assigns scores (CSS) to the news to reflect linguistic tone, from 0 (very negative news) to 100 (very positive news), with 50 being neutral. The CSS scores cover more than 330 different types of news events, including product recalls, earnings announcements, layoffs, M\&A activity, etc. We use this 
information to construct a proxy for public signals: News Sentiment $(N S)$, which is defined as the average CSS of all news reports about a firm over the six month period. Similar to the case of analyst reports, we standardize each distribution of the News Sentiment index with respect to each country.

Our main proxies for country-level governance come from Acemoglu and Johnson (2005). Contracting institutions (horizontal governance) refer to the rules and regulations governing contracting between two parties of similar power, such as those between creditor and debtor. Property rights institutions (vertical governance) refer to the rules and regulations protecting market participants against the power of the government (or the elite). The three contracting indices include legal formalism (the index of formality in legal procedures for collecting on a bounced check), procedural complexity (the index of complexity in collecting a commercial debt), and the number of procedures (the number of procedures involved in collecting a commercial debt). The three property rights indices are constraints on the executive (whether there are regulatory limitations on the executive's actions and authority), average protection against expropriation (protection against the risk of expropriation of private foreign investment), and private property protection. Acemoglu and Johnson (2005) provide a more detailed discussion on the different roles played by the two institutions. ${ }^{10}$

Given that the original indices have different distributions, we standardize them to be distributed between 0 (perfect governance) and 1 (weakest governance). Then, we take the average of the three horizontal and vertical governance measures to obtain two representative indices. We report a graphical view of these indices in Figure 1 (these governance indices are static in nature). In terms of horizontal governance, Australia is regarded as the best and Peru the worst. In terms of vertical governance, Luxembourg and the U.S. are among the best, and China and Peru are among the worst. We also use a series of alternative measures of governance. These are disclosure (Bushman, Piotroski, and Smith 2004), the poor governance index (computed as the inverse of the good government index of Karolyi, Lee and van Dijk, 2012), anti-self-dealing (Djankov, La Porta, Lopez-de-Silanes and Shleifer 2008), accounting transparency (Durnev, Errunza and Molchanov 2009), and the Corruption Perceptions Index (Transparency International).

\footnotetext{
${ }^{10}$ Acemoglu and Johnson (2005) do not have Germany in their data sample - and neither do we.
} 


\section{Summary Statistics}

We report summary statistics of the final sample in Table I. Panel A tabulates the summary statistics over the 2000-2009 period based on a semi-annual sampling frequency. The first six columns report the total number of observations and the whole-sample distribution of our main variables, including the mean, standard deviation, minimum, median, and maximum values of these variables. To further demonstrate the potential influence of country-level governance, we break down the countries in our samples into five governance quintiles and compute the average values of our main variables in each governance quintile. We report this quintile distribution in the next ten columns. The summary statistics can be further detailed at the country level— to save space, they are provided in the Internet Appendix.

The first part of Panel A tabulates the above distributions for the main stock characteristics that are used as dependent variables, including book-to-market ratio $(B / M)$, monthly return $($ Ret $)$, DGTWadjusted return $(D G T W)$, idiosyncratic volatility (Idiosyn Vol), Amihud illiquidity, the proportion of zero daily firm returns in a period (Zero Return), and Tobin's Q. Appendix B provides the definitions of all variables.

If we focus on the overall sample, the statistics for these variables are similar to those reported in the literature. For example, in Lau, Ng, and Zhang (2010), the monthly return averages approximately $1 \%$ across stocks in different countries, compared with the mean of $1 \%$ in our sample. If we compare our statistics with Karolyi and Wu (2012), the largest up-to-date sample, our starting stock sample of 45,343 firms from Datastream/WorldScope and CRSP is comparable to Karolyi and Wu (2012), with a total stock number of 37,399. After matching with FactSet/LionShares and I/B/E/S, our final sample is smaller and concentrates on the large firms. The governance-quintile distribution of the variables suggests that country-level governance (associated with high quintile ranks) may directly affect illiquidity, but less so for idiosyncratic risk and stock price (such as DGTW return and Tobin's Q). The former pattern is not surprising, as country characteristics related to governance, such as market size and information quality, may affect liquidity. Due to this observation, our later analysis also directly controls for country-fixed effects. 
The second part of Panel A tabulates the entire sample and quintile distribution of the variables related to public or semi-public information, including the number of analysts following the firm (\# Analyst), the percentage of firms covered by analysts in a country (\%Analyst coverage), the average value of analyst recommendations in the sample $(R e)$, news sentiment $(N S)$, analyst recommendation changes $(\Delta R e)$, and news sentiment changes $(\Delta N S)$. The last two variables are our main proxies for semi-public and public information. Our Internet Appendix provides more detailed country level distribution of these variables. More specifically, we report the time-series average of semiannual medians of the information variables in each country, following Karolyi and Wu (2012).

We can see that analyst coverage is substantial in global markets and is typically approximately $70 \%$ of the stocks in each country. Although analysts tend to follow larger stocks, the high coverage ratio reduces concerns about sample selection. By contrast, the coverage of Dow Jones news media is more concentrated, and there is a wide country-level variation in the number of news items reported for each stock. Developed countries typically have higher media coverage, whereas firms in countries with poor governance are typically much less covered by the Dow Jones news, which is consistent with the notion that public information is less available in these countries. Because the use of this variable would reduce the number of firms particularly in countries with poor governance, our main empirical tests will focus only on semi-public information. However, we will use this proxy of public information - and its accompanying smaller sample - to explore and differentiate the economic impacts of the two sources of information.

The third part of Panel A summarizes the pooled distribution of mutual fund turnover in stocks $\left(\% \Delta\right.$ Hold $_{i, k, t}$, referring to the percentage rebalancing of stock $i$ in period $t$ by fund $k$ ) and the distribution of our main independent variables - the use of semi-public information in countries with good governance (SemPub_Good) and the incremental use of semi-public information in countries with poor vertical and horizontal governance (SemPub_Poor) by the representative mutual fund ownership of a stock. We will explain their construction in the next section. Here, we simply note that 
both fund turnover and our independent variables have reasonably wide distributions. ${ }^{11}$ Furthermore, the quintile distribution illustrates a weak correlation between the use of semi-public information increases and poor governance, which lends preliminary support to our main hypothesis. Of course, the correlation also suggests that fund investment decisions may be clustered in a given country. Together with the previous discussion on country-fixed effects, this possibility motivates us to control for country and time-fixed effects. We further follow Petersen (2009) to cluster the errors at the country and time level for our stock-level regressions to control for within-cluster dependence uncaptured by the time or country dummies. Following the literature, we also use different sets of control variables that cater to different dependent variables. We will detail the variable lists and the reasons for using them when we explain the regression models. The Internet Appendix provides their distributions.

Finally, we report the correlation matrix of the dependent and independent variables in Panel B and that of the main and alternative governance indices in Panel C. Panel B illustrates that the use of semi-public information induced by poor country-level governance is generally related to less liquidity, more idiosyncratic risk, and lower Tobin's Q. Meanwhile, Panel C suggests that horizontal and vertical governance are highly correlated, which is not surprising because developed (emerging) countries tend to be better (worse) along both dimensions. In many countries, however, the relation between the two governance dimensions is different. China, for example, has extremely poor property rights institutions, whereas its contracting institutions are of average quality.

\section{The Use of Semi-public Information and Quality of Governance}

In this section, we investigate the link between the use of semi-public information and governance, and we establish the profitability of strategies based on it.

\section{A. Semi-public information and fund behavior}

\footnotetext{
${ }^{11}$ In our sample, fund turnover has a mean of $-2.21 \%$ and a standard deviation of $73 \%$. Several normality tests (Cramer-von Mises and Kolmogorov-Smirnov) reject the null hypothesis that the variable has a normal distribution, implying that some structural models, such as the one we will describe in equation (1), are perhaps required to understand the formation of the variable.
} 
We begin by studying whether mutual funds use semi-public information differently depending on the quality of governance of the country whose stock they invest in. Thus, for each fund, we regress the percentage rebalancing of fund $k$ in split-adjusted holdings of stock $i$ over the semi-annual period on the contemporaneous changes in analyst recommendations $\Delta R e_{i, t}$, country-level governance, and the interaction between governance and changes in analyst recommendations, in addition to a set of control variables. More specifically, we estimate for each fund in a given period:

$$
\% \Delta \operatorname{Hold}_{i, k, t}=a_{k, t}+\lambda_{k, t}^{*} \Delta \operatorname{Re}_{i, t}+\lambda_{k, t}^{G} G_{i}+\gamma_{k, t} \Delta R e_{i, t} \times G_{i}+c \times M_{i, t-1}+\varepsilon_{i, k, t}
$$

where $\% \Delta H o l d d_{i, k, t}$ refers to the percentage rebalancing of stock $i$ in period $t,{ }^{12} \Delta R e_{i, t}$ is the change in the analyst forecast of the stock, $a_{k, t}$ is the regression constant, $\lambda_{k, t}^{*}$ is the sensitivity to semi-public information when country-level governance is perfect, $G_{i}$ is the index of the quality of governance of the country of stock $i$ (it is static and thus does not have a time lag), $\lambda_{k, t}^{G}$ is the sensitivity to governance, and $\gamma_{k, t}$ captures the mutual funds' incremental sensitivity to semi-public information in the presence of poor governance. The vector of $M_{i, t-1}$ stacks potential control variables, including country and industry return, and lagged analyst recommendation changes. Because the semi-public information contained in the analyst reports becomes public after the full release of these reports, we focus on the contemporaneous relationship between fund trading and analyst recommendations. In this case, the sensitivity of managers' trading to contemporaneous analyst recommendations describes the degree to which fund managers use semi-public information to trade.

Table 2 reports the average value of the regression coefficients and the corresponding robust $t$ statistics. We see that fund rebalancing correlates positively with the contemporaneous changes in analyst recommendations. Even more importantly, the effect is stronger in the case of poor countrylevel governance and is economically significant. For example, in columns 2 and 3, a one-standarddeviation increase in changes in analyst recommendation induces funds to increase their stock holdings by $1.03 \%$ and $6.23 \%$ for stocks in countries with the best horizontal and vertical governance, respectively. The corresponding figures in countries with poor governance are much higher. They are

\footnotetext{
${ }^{12}$ We follow Kacperczyk and Seru (2007) in capping the percentage change in stock turnover at $100 \%$ (4.6\% of the stock turnover is above $100 \%$ ). We have also verified that different thresholds will not qualitatively change our main results.
} 
$17.2 \%$ and $17.8 \%$ for Peru and China, which have the worst overall ratings for horizontal and vertical governance, respectively, and $15.6 \%$ and $16.8 \%$ in the five worst countries (Peru, Argentina, Mexico, Philippines, and Spain for horizontal governance and China, Peru, Indonesia, Sri Lanka, and Romania for vertical governance). ${ }^{13}$ All these numbers are highly statistically significant. In addition, these results remain largely unchanged if we further control for lagged semi-public information and market or industry-wide information.

We rely on equation (1) to define two fund-level measures that capture the importance of semipublic information in explaining portfolio turnovers. The first is the partial $R^{2}$ of $\lambda_{k, t}^{*} \Delta R e_{i, t}$, which we

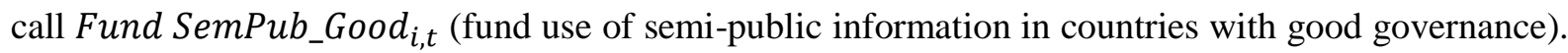
It describes the use of semi-public information conditional on strong institutions. The second measure is the partial $R^{2}$ of the $\gamma_{k, t} \Delta R e_{i, t} \times G_{i}$ term, which we call Fund SemPub_Poor ${ }_{i, t}$ (fund use of semipublic information in countries with poor governance). It represents the effect of the use of semipublic information induced by (conditional on) poor country-level governance. These two measures summarize how the funds use semi-public information in countries with varying qualities of governance. Semi-public information typically explains 3.8\% (mean value) of portfolio turnover for funds when the governance of a country is good. Poor country-level governance increases fund managers' use of semi-public information by $3.3 \%$ with respect to the unconditional value.

More importantly, to examine how the governance-induced use of semi-public information affects asset pricing, we build stock-level measures that aggregate the fund-level use of semi-public information for all the funds that invest in the stock. That is, we define SemPub_Poor ${ }_{i, t}=$ $\sum_{k}$ Fund SemPub_Poor $_{i, k, t} \times H_{i, k, t}$ and SemPub_Good ${ }_{i, t}=\sum_{k}$ Fund SemPub_Good $_{i, k, t} \times H_{i, k, t}$, where Fund SemPub_Poor ${ }_{i, k, t}$ and Fund SemPub_Good ${ }_{i, k, t}$ proxy for the use of semi-public information by fund $k$ that has invested in stock $i$ depending on the quality of governance in the

\footnotetext{
${ }^{13}$ An alternative way to test equation (1) is to first compute the fund use of semi-public information without interacting the $\Delta R e_{i, t}$ with governance, i.e., we first run the regression $\% \Delta \operatorname{Hold}_{i, k, t}=a_{k, t}+\lambda_{k, t}^{*} \Delta R e_{i, t}+\varepsilon_{i, k, t}$. We then regress the $R^{2}$ from the regression on the quality of country governance. The Internet Appendix confirms that our conclusion remains the same. The reason we adopt equation (1) as our main specification is that the interaction term separates the specific information impact of country governance from the general country-fixed effects, which allows us to take advantage of the time variation in analyst recommendations (governance indices are static) and construct time-varying independent variables that are suitable for asset pricing tests. We are grateful to an anonymous referee for this insight.
} 
country, and $H_{i, k, t}=n_{i, k, t} / N_{i, k, t}$ is the fraction of the stock held by fund $k$ out of all the mutual funds.

The descriptive statistics are reported in Table 1.

\section{B. Semi-public information and profitability.}

We now investigate whether the use of semi-public information is profitable. As we argued, this test is important to both complete the testing of our hypotheses and to validate the choice of empirical proxies for different types of information. Following Carhart (1997) and Kacperczyk and Seru (2007), we first estimate fund performance based on a 36-month rolling window. ${ }^{14}$ We consider alternative measures of risk adjustment — the one-factor alpha of Jensen (1968), the three-factor alpha of Fama and French (1993), and the four-factor alpha of Carhart (1997) - to measure fund performance. Given that the results are similar, we only report those based on the four-factor alpha.

Then, we regress performance on the use of semi-public information associated with good governance and the use of semi-public information induced by poor governance (Fund SemPub_Good and Fund SemPub_Poor) and a set of control variables in a panel specification with country and timefixed effects. We cluster the errors by country and time. Fund control variables include the expense ratio, portfolio turnover, and fund size (defined in terms of total net assets). The analysis is conducted semi-annually to be consistent with the sampling frequency of the Fund SemPub_Poor variables.

The results are reported in the first two columns of Table 3 . They display a strong and significant positive relationship between fund performance and Fund SemPub_Poor. More specifically, a onestandard-deviation increase in Fund SemPub_Poor is related to a 39 bps higher annualized performance for vertical governance and a 38 bps higher performance for horizontal governance. Consistent with the findings of Kacperczyk and Seru (2007), the use of analyst information in countries with good governance (Fund SemPub_Good) is negatively related to performance,

\footnotetext{
${ }^{14}$ More specifically, we estimate the factor loadings of funds based on the 36-month period prior to $t$ and then compute the performance of the fund in month $t$ as the difference between the realized fund return in month $t$ (in excess of the risk-free rate) and the realized risk premium in the same month (i.e., the product of the vector of rolling factor loadings times the realized factor return in month $t$ ). We then average the monthly performance in a semi-annual period as the performance of the period. Finally, we annualize the performance of funds in each period.
} 
suggesting that the information content of analyst reports is very different in "bad" countries as opposed to "good" countries.

The next two columns include the incremental use of public information induced by poor countrylevel governance (Fund Pub_Poor). As discussed above, we do not use pure public information in our main tests because the proxy for public information reduces the sample and may induce selection problems across countries. After having established the preliminary results based on analysts, however, the side-by-side tests provide a nice robustness check to further validate our previous analyses. The fund use of public information is estimated by including in equation (1) the public information released from news media $(\Delta N S)$ and its interaction with country governance. In the interest of brevity, we report the results of this augmented first-stage regression in the Internet Appendix. It suffices to say that, in the first-stage regression, the partial $R^{2}$ of the interaction term allows us to define the incremental impact of poor governance on fund use of pure public information. We denote this variable as Fund Pub_Poor. In columns (3) and (4), we report the impact of Fund Pub_Poor on fund performance side-by-side with that of Fund SemPub_Poor. We can see that the side-by-side use of public and semi-public information does not absorb the explanatory power of the use of semi-public information on fund performance and that there is no relation between the use of pure public information (Fund Pub_Poor) and performance. These results are consistent with our interpretation of semi-public information and validate our choice of the empirical proxy.

\section{Effects on the Stock Market}

In this section, we relate poor governance-induced use of semi-public information (SemPub_Poor) to stock characteristics.

\section{A. Stock Liquidity and Idiosyncratic Volatility}

We begin by investigating the impact of SemPub_Poor on stock liquidity and idiosyncratic volatility . We estimate the following:

$$
\text { Char }_{i, t+1}=\alpha+\beta_{1} \times \text { SemPub_Poor }{ }_{i, t}+\beta_{2} \times \text { SemPub_Good }_{i, t}+c \times M_{i, t}+\varepsilon_{i, t+1} \text {, }
$$


where $\operatorname{Char}_{i, t+1}$ is the one-period-ahead stock characteristic - e.g., liquidity or idiosyncratic volatility - and the coefficients $\beta_{1}$ and $\beta_{2}$ represent the sensitivity of the stock characteristics (e.g., liquidity) with respect to stock-level SemPub_Poor and SemPub_Good. The vector $M_{i, t}$ stacks the control variables. For both liquidity and idiosyncratic volatility, we control for the volatility of fund flows (Flow_Std), which may provide flow-based motivations for funds to trade, such as fire sales (e.g., Coval and Stafford 2007). We also control for standard firm characteristics, such as book-to-market ratio $(B M)$, the logarithm of firm size (LogSize), and institutional ownership (IO) and additional variables that are known to affect the dependent variable in the literature, which we will describe shortly. These variables are defined in Appendix B and are lagged by one period. We estimate a panel with time and country-fixed effects and cluster the errors by country and year.

Table 4 reports the results of the specifications in which illiquidity is used as the dependent variable. In columns 1 to 4, illiquidity is proxied by the Amihud (2002) measure, which is computed as the logarithm of one plus the absolute return per dollar of trading volume. We further control for seasonality in the spirit of Chordia et al., (2005), Hameed et al., (2010) and Karolyi et al., (2012), as detailed in Appendix B. Columns 5 to 8 define illiquidity as the proportion of zero daily firm returns in a period (Zero Return). Bekaert et al., (2007) demonstrate that this measure better captures the impacts of liquidity than traditional measures such as turnover, in emerging markets. ${ }^{15}$ Columns (1), (3), (5), and (7) present our main results. As a robustness check, we also control for the firm governance index from Aggarwal et al. (2009) in the remaining columns, as well as a dummy variable that takes the value of 1 when the firm governance index is available and zero otherwise in order to control for the potential fixed effect of firms that do not have corporate governance data. ${ }^{16}$ Finally, we follow Gopalan et al. (2012) and further control for variables that are known to affect firm liquidity, such as the level of cash over the total assets of the firm (Cash/TA), capital expenditures (CAPEX), returns on assets (ROA), and the buy-and-hold return over the previous 6 months (MOM).

\footnotetext{
${ }^{15}$ The implication of country-level governance on turnover is ambiguous in our extension of Kim and Verrecchia (1994). As discussed in Appendix A, the effect depends on the relative mass of informed as opposed to discretionary liquidity traders. Thus, we do not include it as a main dependent variable.

${ }^{16}$ Similar to our country-level governance, we normalize the firm-level governance index with 1 for the weakest governance and 0 for the best governance.
} 
We find a strong positive correlation between SemPub_Poor and illiquidity across the different specifications and for the alternative measures of governance. A one-standard-deviation increase in SemPub_Poor defined in terms of horizontal governance is related to an $11 \%$ higher Amihud illiquidity and a $3.4 \%$ proportion of zero return days. The analogous figures for vertical governance are $15 \%$ and $2.9 \% .{ }^{17}$ The results are qualitatively and quantitatively similar in the specification in which we control for firm-level governance.

Table 5 reports the results for the specifications in which idiosyncratic volatility is used as the dependent variable. Due to its skewness, we transform idiosyncratic volatility by adding 1 and taking the log transformation. We follow Bartram et al. (2012) and Bekaert, Hodrick, and Zhang (2012) to compute idiosyncratic volatility using an international version of the Fama-French factor model that is based on three domestic factors and three international factors in Columns (1) to (4). As a robustness check, we also report in Columns (5) to (8) the results based on idiosyncratic volatility computed using a model that contains both industry and market factors following the same paper. Our results do not change when we use other factor models, including the CAPM model, the domestic Fama-French three-factor model, and the Carhart four factor model.

Finally, in addition to the common control variables, we follow Bartram et al. (2012) and further control for a list of variables that may affect volatility in the global market, including ICRG Political risk, the creditor rights index, the anti-director index, stock market turnover, stock market capitalization (\%GDP), private bond market (\%GDP), equity market liberalization, disclosure, PPE/TA, ROA, Cash/TA, debt maturity, R\&D, Zero Return, age(log), and leverage. All these variables are defined in Appendix B.

\footnotetext{
${ }^{17}$ The economic magnitude for the regression of $y=\beta \times x$ is computed as $\beta \times \sigma_{x} /|\bar{y}|$, where $y$ and $x$ are the dependent and independent variables, respectively, $\beta$ is the regression coefficient, $\sigma_{x}$ is the standard deviation of $x$, and $\bar{y}$ is the mean of $y$. For instance, the standard deviation of horizontal SemPub_Poor is 0.022, the regression coefficient in column (1) is 0.336, and the average Amihud illiquidity is -0.066 . From these numbers, we compute the economic magnitude as $0.022 \times 0.336 / \mid-$ $0.066 \mid=11.2$, which means an $11 \%$ increase in illiquidity. Note that we use this interpretation because later on we want to understand the impact of semi-public information on the level of crisis - i.e., how SemPub_Poor pushes stock characteristics away from their mean values during crisis. Alternatively, we can also use the standard deviation of the dependent variable to scale the economic magnitude. In this case a one-standard-deviation increase in SemPub_Poor defined in terms of horizontal (vertical) governance is related to a 4\% (5\%) higher Amihud illiquidity and a 2\% (1.6\%) proportion of zero return days. However, these numbers may under-estimate the impact of semi-public information on the liquidity condition of the market as a whole. Hence, we mainly use the former scaling method - but we also report the latter scaling when applicable.
} 
The results show a highly significant positive relation between idiosyncratic volatility and SemPub_Poor, which holds across the different specifications and for the alternative measures of governance. In particular, a one-standard-deviation increase in SemPub_Poor defined in terms of horizontal (vertical) governance is related to a $2.5 \%(2.2 \%)$ higher idiosyncratic volatility in column 1 (3). ${ }^{18}$ As before, the results are qualitatively and quantitatively similar if we control for the firmspecific level of governance.

These results support our second hypothesis that the governance-induced use of semi-public information translates into higher informativeness of the stock price - idiosyncratic volatility (e.g., Morck et al., 2000 and Jin and Myers, 2006) - and simultaneously reduces liquidity when the quality of governance is worse. They also confirm the unique role of contracting in the financial service industry, as observed by Acemoglu and Johnson (2005).

\section{B. Stock Reaction and Firm Value}

One potential concern is that, although the proxies of liquidity are relatively clean, idiosyncratic risk may not be a powerful proxy for stock price informativeness. Bartram et al. (2012), for instance, report that country risk, investor protection, financial development and openness, disclosure and noise trading, and growth opportunities can all affect idiosyncratic risk. Thus, in this section, we first provide an additional test based on the stock price reaction to verify the impact of SemPub_Poor on stock informativeness. We then examine the overall net effect on the stock value of the poorgovernance-induced use of semi-public information.

The additional test investigates the impact of SemPub_Poor on the stock reaction to semi-public information releases. The standard informed trading model (e.g., Kyle 1985) suggests that informed trading allows the market to incorporate information at a higher speed. If so, we would expect SemPub_Poor to enhance the stock reaction to the release of semi-publicinformation, making it more positive in the case of good news and more negative in the case of bad news. To test this conjecture, we use both the raw returns and the DGTW-adjusted abnormal return as our dependent variables. The

\footnotetext{
${ }^{18}$ The impacts are $5 \%$ and $4 \%$ when scaled by the standard deviation of the dependent variable.
} 
DGTW adjustment follows Daniel et al., (1997) and uses the benchmark return constructed from the portfolios that are matched with the stocks held in the evaluated portfolio based on the size, book-tomarket and prior-period return characteristics of such stocks. We decompose the sensitivity of returns to information into reactions to positive and negative information and estimate the following semiannual panel regression with country and time-fixed effects, and errors clustered at the country and time level:

$$
\begin{aligned}
\text { Ret }_{i, t+1}=\alpha+\beta_{1 g} & \times \text { SemiPub_Poor }_{i, t} \times D_{\text {Good }}+\beta_{1 b} \times \text { SemiPub_Poor }_{i, t} \times D_{\text {bad }}+\beta_{2 g} \times \text { SemiPub_Good }_{i, t} \\
& \times D_{\text {Good }}+\beta_{2 b} \times \text { SemiPub_Good }_{i, t} \times D_{\text {bad }}+c \times M_{i, t}+\varepsilon_{i, t+1}
\end{aligned}
$$

where $\operatorname{Ret}_{i, t+1}$ is the price reaction of stock $i$, proxied by either the raw return and or the DGTW return, $D_{\text {good }}$ and $D_{b a d}$ are dummy variables that refer to positive and negative changes in standardized analyst recommendations, SemiPub_Poor ${ }_{i, t}$ and SemiPub_Good ${ }_{i, t}$ are the use of semipublic information induced by poor governance or good governance, respectively, and the vector of $M_{i, t}$ stacks a list of control variables as in Table 4, except that we further control for momentum. The parameters of $\beta_{1 g}$ and $\beta_{1 b}$ describe the incremental stock reaction to news induced by SemPub_Poor, in addition to what SemPub_Good generates.

The results are reported in Panel A of Table 6, with columns (1) to (4) for raw return and (5) to (8) for DGTW-adjusted returns. These results are consistent across all the specifications and show that poor-governance-induced use of semi-public information (SemPub_Poor) indeed amplifies the stock reaction to both good news and bad news. This effect is also economically significant. For horizontal governance-induced SemPub_Poor, a one-standard-deviation increase is related to a $4.0 \%$ (3.6\%) additional positive return (DGTW return) for good news and a $-2.9 \%(-2.8 \%)$ negative return for bad news. For vertical governance, the analogous figures are $2.3 \%(2.6 \%)$ and $-2.6 \%(-3.2 \%)$.

As an additional robustness check, we also implement a portfolio-based analysis. The results, which we report in our Internet Appendix, are qualitatively and quantitatively similar. These results confirm our working hypothesis that the use of semi-public information by the mutual funds amplifies 
the impact of the news on the stocks, consistent with our previous results that the former improves the informativeness of stocks. ${ }^{19}$

The information discovery role played by the funds is both beneficial - in terms of improving the informativeness of the stock price - and costly - in terms of reducing liquidity. It is therefore important to detect the overall impact of SemPub_Poor by examining its impact on stock value. We follow Hong and Kacperczyk (2009) and alternatively regress market-to-book and Tobin's Q on SemPub_Poor and a set of control variables that could affect the dependent variable, including, among others, $R \& D$ (research and development expenditure as percentage of total sales) and firm profitability, proxied by the concurrent and next two periods' return on equity (ROE, FROE, F2ROE).

We report the market-to-book results in columns (1) to (4) and the Tobin's Q results in columns (5) to (8) in Panel B. The results provide evidence of a negative relationship between SemPub_Poor and stock value in general. For instance, the impact of SemPub_Poor on market-to-book is significantly negative for both vertical and horizontal governance. A one-standard-deviation increase in SemPub_Poor is related to a $1.5 \%$ lower market-to-book and $1.2 \%$ Tobin's Q for vertical governance and impacts of similar magnitude for horizontal governance.

Taken jointly, these results suggest that, again, mutual funds play a special role in promoting information in economies with poor governance. However, the cost more than offsets the positive effects of better information. Thus, the role of mutual funds with respect to processing semi-public information in countries with poor governance reduces firm value.

\section{Extensions}

We now consider extensions to further enrich our economic insight. First, we examine whether the cost of poor-governance-induced semi-public information is particularly relevant during the financial crisis. Second, we investigate potential endogeneity issues. Finally, we conduct a series of robustness checks and discuss, among other topics, the role of public information, short-selling constraints and alternative proxies of governance.

\footnotetext{
${ }^{19}$ Although in the interest of space we only tabulate the panel regressions with country- and year-fixed effects and clustering at the country and year level, our main conclusions in the second stage are also robust to Fama-Macbeth regressions.
} 


\section{A. The Use of Semi-public Information and the Financial Crisis}

To understand the cost of poor-governance-induced semi-public information during the financial crisis, we examine how the pre-crisis level of SemPub_Poor and SemPub_Good affected the changes in stock prices and liquidity around the crisis, from the pre-crisis period (2005-2007) to the crisis period (2008-2009). We first estimate the following cross-sectional regression with a country-fixed effect for illiquidity:

$$
\Delta \text { Char }_{i}=\alpha+\beta_{1} \times \text { SemPub_Poor }_{i}+\beta_{2} \times \text { SemPub_Good }_{i}+c \times M_{i}+\varepsilon_{i},
$$

where $\Delta$ Char $_{i}$ is the change in illiquidity from the pre-crisis period to the crisis period for stock $i$, and the other variables are defined as before. All the control variables are computed as the mean of their pre-crisis period values. Because this is a pure cross-sectional regression, we no longer have the time dimension to control for time-related effects.

We report the results in Table 7, which shows a strong positive relationship between pre-crisis SemPub_Poor and increases in illiquidity during the crisis. More specifically, within the context of weak horizontal governance, a one-standard-deviation higher SemPub_Poor leads to a $31 \%$ increase in Amihud illiquidity during the crisis period. The analogous figures for the case of weak vertical governance are $27 \% .{ }^{20} \mathrm{We}$ see that the impact on illiquidity is much more substantial than we observed for normal periods. These findings not only confirm the previous results but also suggest that the cost of having some (more capable) investors to process semi-public information is high when the market requires liquidity.

Next, we focus on stock returns. During the crisis, the semi-public information is mostly negative because most of the news about the firms is bad. We would therefore expect to see a steeper price drop in the presence of SemPub_Poor. Table 8 tests this conjecture. The dependent variable is the change in the value of stock $i$, as proxied by the average monthly DGTW return of stock $i$ during the 2008-2009 crisis period and the increment of market-to-book ratios from the pre-crisis period to the crisis period. We also consider raw returns and Tobin's Q, but because the results are similar and in the interest of

\footnotetext{
${ }^{20}$ The two numbers translate into $10 \%$ and $8 \%$ of the standard deviation of illiquidity. These two numbers, however, may understand the market-wide impact of SemPub_Poor during crisis as mentioned.
} 
brevity we only report and discuss those based on DGTW returns and market-to-book. We find a negative relationship, which is consistent with our previous panel regression results. Indeed, a onestandard-deviation higher SemPub_Poor is related to a 5.3\% lower DGTW-adjusted return and a 5.8\% lower market-to-book ratio during the crisis period in the case of horizontal governance and a $3.9 \%$ lower return and $4.4 \%$ lower market-to-book ratio in the case of vertical governance. These numbers are highly significant both statistically and economically, and they demonstrate the level of impact that the quality of country-level governance can have on the market during a crisis period.

\section{B. Endogeneity Issues}

One potential concern is that the choice of assets in the fund portfolios might be endogenous with respect to the governance regime: mutual funds may simply invest more in assets that exhibit high SemPub_Poor in countries with poor governance, rather than processing more semi-public information for these stocks. In other words, SemPub_Poor may proxy for some unobserved characteristic of the assets that is used by investors to select assets without any superior information. For example, it may be that the assets that react more to information are more appreciated in poor governance countries because they impound information more quickly and are therefore less subject to governance issues.

We provide two pieces of evidence to verify that SemPub_Poor is related to the processing of new semi-public information rather than to the selection of stocks with certain characteristics. The first evidence, as we have observed above, is that the fund-level use of semi-public information is related to superior performance, which is not the case for public information. The link to performance implies that funds trading high SemPub_Poor stocks are informed about these stocks, which would only (if anything) discourage uninformed funds from investing in such stocks.

Second, in the case of reverse causality, we would expect that in the presence of an improvement in governance: 1) the demand for high SemPub_Poor assets would decline as the preference of the funds for these stocks drops; and 2) SemPub_Poor would not change. By contrast, if the causality is as we have argued, we would expect the following: 1) the demand for high 
SemPub_Poor assets would not change; and 2) stock-level SemPub_Poor would decrease as funds began to process less semi-public information. In other words, in the presence of reverse causality, we would expect a change in ownership on high SemPub_Poor stocks, whereas, according to our hypothesis, we would expect a change in SemPub_Poor for all the stocks. Therefore, the two alternatives can be tested based on the following two regressions:

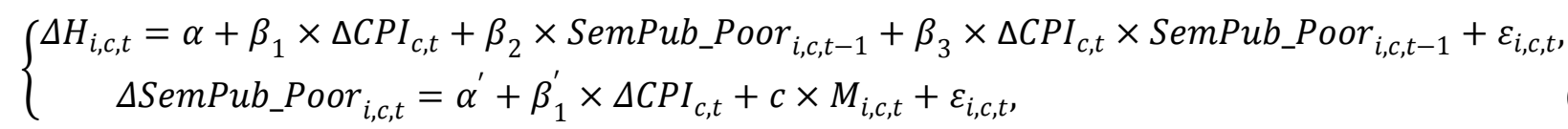

where $\Delta H_{i, c, t}$ is the percentage change in the holdings of stock $i$ in the aggregate mutual fund holding portfolio in country $c$ (where the stock is traded) over the period of $t, \Delta S e m P u b_{-} P_{0 o r}, c, t$ is the change in value of SemPub_Poor of the stock over period $t$ conditioned on the fund ownership information observed at $t-1$ (recall that we require fund ownerships to compute stock SemPub_Poor), and $\triangle C P I_{c, t}$ is the change in country-level governance, which is proxied by the annual change in the Corruption Perceptions Index of the country. The Corruption Perceptions Index ranges from 0 (very clean) to 10 (highly corrupt). Here, we use this index because its annual changes are available to most countries. Accordingly, in order to align with the data frequency of this index, the regressions are conducted annually.

The reverse causality hypothesis predicts $\beta_{3}$ to be positive in (5A) because the demand for high SemPub_Poor stocks increases (decreases) more when governance deteriorates (improves). By contrast, our hypothesis predicts $\beta_{1}^{\prime}$ in (5B) to be positive because more (less) corruption increases (reduces) the use of semi-public information. The results are reported in Table 9. The first two columns tabulate the regression of (5A). The coefficient of $\beta_{3}$ is negative or positive but insignificant, which rejects reverse causality. The next two columns tabulate the regression of (5B), in which $\beta_{1}^{\prime}$ is consistent with our hypothesis. These results provide a second piece of evidence in favor of the causality predicted by our story. Combined, our tests confirm that SemPub_Poor involves an active role for mutual funds in processing information, which fits our intuition that mutual funds play a pivotal role in transferring the indirect impact of country-level governance to the stock market. 


\section{Robustness checks}

We now consider a set of robustness checks. In the interest of space, we tabulate the detailed regression results in the Internet Appendix and only discuss the general methodology and results here.

We first investigate how poor governance induces funds to use semi-public information side by side with pure public information by re-estimating equation (1) and including $\triangle N S$, the proxy for unprocessed public information, and its interaction with country governance. The results are reported in Table A1 in the Internet Appendix. The most important observation is that, unlike the case of analyst recommendations, the interaction between pure public information and governance has a negative impact on stock turnover. The negative sign is consistent with the idea that poor governance makes funds use less pure public information and more semi-public information.

Next, we examine how country-level constraints on short-selling may affect the pricing impact of SemPub_Poor. We know that in the presence of differences in opinions among investors, constraints on short-selling may lead to stock price crashes (e.g., Hong and Stein, 2003). Hence, we want to verify that the empirical power of SemPub_Poor (particularly during the crisis period) does not come from this alternative mechanism. We use as a proxy for short-selling a dummy variable (NoShort) that takes the value of 1 if a stock is in countries in which short sales are not allowed, or in countries/ industries that experienced short sale bans during the crisis period, and zero otherwise. The list of short-selling bans is derived from Beber and Pagano (2013). We also include the interactions between the dummy variable and SemPub_Poor and SemPub_Good.

Two main results emerge from Table A2 in the Internet Appendix. First, controlling for short-sale constraints does not absorb the impact of SemPub_Poor on crisis period variables, including the crisis period DGTW return and Amihud illiquidity. Second, the interaction between short-sale constraints and SemPub_Poor has insignificant impacts. These observations confirm that (weak) governance contributed to the recent global financial crisis in a manner that is different from that of diverging opinions and short-sale constraints. 
In the third robustness check, we experiment with alternative measures of country-level governance. We consider the poor government index (the reverse of the good government index) from Karolyi, Lee, and Van Dijk (2012), the index of disclosure (Disclose) from Bushman, Piotroski, and Smith (2004), the anti-self-dealing index (Anti_SD) from Djankov, La Porta, Lopez-de-Silanes, and Shleifer (2008), and the accounting transparency measure (Acc Transparency) from Durnev, Errunza, and Molchanov (2009). Similar to our main governance variables, we scale the alternative indices to be between 0 (good) and 1 (poor). We expect these alternative governance indices to have a significant impact on stock market characteristics because they are also capable of identifying weak institutions that may reinforce the benefit of semi-public signals (relative to public signals) and induce capable traders to use more semi-public information.

Table A3 in the Internet Appendix shows that weak governance using these alternative governance proxies is related to fund managers' use of semi-public information. We also observe that SemPub_Poor increases illiquidity and price informativeness (the reaction of stock return to semipublic information). The parameters and economic significance are comparable to the SemPub_Poor based on our main proxies of governance. (Unreported) tests on the crisis period confirm that the SemPub_Poor of these alternative governance measures have a similar crisis period impact to that of our main governance variables. Thus, our results are robust to these alternative governance measures.

The alternative measures are not necessarily orthogonal to our main governance variables. The reason we do not mostly focus on them is that, unlike our main proxies, these alternative variables lack the flexibility to systematically attribute stock market characteristics not only to the vertical relationships between commoners and the elite (i.e., property rights institutions) but also to the horizontal relationships between market participants (i.e., contracting governance). However, the notion that weak governance induces funds to process semi-annual information, which further affects asset prices, is fully supported by all the indices.

In addition to these main robustness checks, we also show that our main conclusions are robust if we use all six individual governance indices of Acemoglu and Johnson (2005)—recall that in our main tests, the six indices are aggregated into two representative contracting and property rights indices- 
and/or their log values, when we use the log-transformation of SemPub_Poor, or when we restrict the sample to the top 20 countries. These tests confirm that our results are not driven by a few outliers, such as extreme governance values or extreme SemPub_Poor estimations.

Furthermore, two alternative methods of estimating equations (1) and (3) yield similar conclusions. As we mentioned in footnote 10, an alternative way to test equation (1) is to first compute the fund use of semi-public information without interacting semi-public information with governance, and then to regress the $R^{2}$ from the regression on the quality of country governance. The results in Table A5 confirm that poor country governance induces funds to use more semi-public information. Our main specification in equation (1), on the other hand, allows us to take advantage of the time variation in analyst recommendations (governance indices are static) and construct time-varying independent variables that are suitable for asset pricing tests. Finally, our results are robust to the frequency of the estimations (to estimate Fund SemPub_Poor on a quarterly basis when feasible—our results are based on a semi-annual estimation frequency to involve more funds) and various cutoff thresholds on foreign equity holdings $(30 \%$ and $80 \%$, in addition to the $50 \%$ thresholds in our main tests). We tabulate these results and detail our discussions in the Internet Appendix. All these additional tests confirm that our results are economically and statistically robust.

Overall, these results offer a coherent perspective. They show that mutual funds partially offset the negative impact of poor country governance on the quality of public information - but such an improvement is achieved at the cost of increased information asymmetry and, thus, illiquidity. Country-level governance, therefore, plays a fundamental role in shaping financial markets: sophisticated market participants cannot compensate for the negative impact of poor governance without negatively affecting some market conditions.

\section{Conclusion}

We study how country-level governance affects the availability and transmission of information in the market. Poor country-level governance reduces the usefulness of public information in the market, which induces some investors (e.g., fund managers) to use their professional judgment to process public information into valuable semi-public information. Trading by these professional investors 
impounds new information into the market, effectively ameliorating its informational efficiency. However, the process of discovering and trading on semi-public information by some traders also increases the information asymmetry and reduces market liquidity. Thus, improvements in price informativeness come at the cost of illiquidity, a cost that can be particularly high during a crisis period in which the extra price drops and liquidity crunches may enlarge the negative impacts of the financial crisis.

We test this hypothesis using data on international mutual funds and international stocks over the period 2000-2009. Using changes in analyst recommendations as proxies for semi-public information, we confirm that weak country-level governance induces fund managers to use more of this type of information. When we use the Dow Jones News releases as a proxy for pure public information and investigate its impact side-by-side with that of semi-public information, we find that poor countrylevel governance makes fund managers use less public information and that the inclusion of public information does not affect the pursuit of semi-public information. More importantly, the use of semipublic information allows funds to generate risk-adjusted performance, whereas the use of public information does not. This finding confirms the usefulness of the empirical proxy of semi-public signals and the economic motivation for funds to process such signals.

Next, to detect the asset pricing impact of such behavior, we aggregate the use of semi-public information at the stock level across all mutual fund ownership and compute a stock-level variable, SemPub_Poor, which describes the extent to which the institutional investors of a stock with poor country governance tend to use more semi-public information than the institutional investors in a stock with good country-level governance. Consistent with our hypotheses, we find that the poorgovernance-induced use of semi-public information (SemPub_Poor) significantly increases the informativeness of a stock as proxied by idiosyncratic volatility as well as the sensitivity of the stock price to information, and it reduces liquidity. The net effect is discounted stock value. We also find that these effects contributed to the impact of the recent global financial crisis and are robust to alternative proxies of governance and endogeneity tests. 
Our findings provide a novel way of looking at the effects of country-level governance on financial markets through the intermediation of mutual funds, which has important normative implications. The task of offsetting the negative impact of country-level governance is costly, implying that country-level governance may have a greater impact than can be directly measured. Indeed, our results suggest that advances in institutions may be a necessary condition to improve the overall conditions of the financial markets. 


\section{References}

Acemoglu, D., and S. Johnson, 2005, Unbundling institutions, Journal of Political Economy 113, 949-995.

Acemoglu, D., Johnson, S., Mitton, T., 2009, Determinants of vertical integration: financial development and contracting costs. Journal of Finance 63, 1251-1290.

Aggarwal, R., I. Erel, R. Stulz, and R. Williamson, 2009, Differences in governance practices between U.S. and foreign firms: measurement, causes, and consequences, Review of Financial Studies 22, 3131-3169.

Amihud, Y. 2002. Illiquidity and stock returns: cross section and time Series effects. Journal of Financial Markets 5, 31-56.

Bae, K.H., R.M. Stulz, and H. Tan, 2008, Do local analysts know more? A cross-country study of the performance of local analysts and foreign analysts, Journal of Financial Economics 88, 581-606.

Bailey, W; H.T. Li, and C.X. Mao, 2003, Regulation fair disclosure and earnings information: market, analyst, and corporate responses, Journal of Finance 58, 2487-2514.

Bartram, S. M., G. Brown, and R. M. Stulz, 2012, Why are US firms more volatile?, Journal of Finance, 67, 13291370.

Beber, A., M. Pagano, 2013, Short-selling bans around the world: evidence from the 2007-09 crisis, Journal of Finance 68, 343-381

Bekaert, G., C. R. Harvey, and C. T. Lundblad, 2007, Liquidity and expected Returns: lessons from emerging markets, The Review of Financial Studies 20, 1783-1831.

Bekaert, G., R. J. Hodrick and X. Zhang, 2012 Aggregate idiosyncratic volatility, Journal of Financial and Quantitative Analysis 47 (6), 1155-1185

Bushman, R., Piotroski, J. and A. Smith. 2004,What determines corporate transparency?: Journal of Accounting Research 42 (2), 207-252,

Carhart, M. M., 1997, On persistence in mutual fund performance, Journal of Finance 52, 57-82.

Chan, K., Covrig, V., Ng, L., 2005. What determines the domestic bias and foreign bias? Evidence from mutual fund equity allocations worldwide. Journal of Finance 60, 1495-1534.

Chang, J., Khanna, T., Palepu, K., 2001. Analyst activity around the world. HBS Working Paper No. 01-061.

Chordia, T., Sarkar, A., Subrahmanyam, A., 2005, An empirical analysis of stock and bond market liquidity, Review Of Financial Studies 18, 85-129.

Cohen L. and Lou D., 2012, Complicated firms, Journal of Financial Economics 104, 383-400.

Coval, J. and Stafford E., 2007, Asset fire sales (and purchases) in equity markets, The Journal of Financial Economics 86(2), 479-512.

Daniel, K., M. Grinblatt, S. Titman, and R. Wermers, 1997, Measuring mutual fund pPerformance with characteristic-based benchmarks, Journal of Finance 52, 1035-58.

DeFond, M., M. Hung, and R. Trezevant, 2007, Investor protection and the information content of annual earnings announcements: International evidence, Journal of Accounting \& Economics 43, 37-67.

Demirguc-Kunt, A. and V. Maksimovic, 1999, Institutions, financial markets, and firm debt maturity, Journal of Financial Economics 54, 295-336.

Djankov S., R. LaPorta, F. Lopez-de-Silanes, and A. Shleifer, 2008, The law and Economics of self-dealing, Journal of Financial Economics 88, 430-465.

Doidge, C., G. A. Karolyi, and R. M. Stulz, 2004, Why are foreign firms listed in the U.S. worth more?, Journal of Financial Economics 71, 205-238.

Doidge, C., G. A. Karolyi, and R. M. Stulz, 2007, Why do countries matter so much for corporate governance?, Journal of Financial Economics 86-1, 1-39.

Durnev A., V. Errunza and A. Molchanov, 2009, Property rights protection, corporate transparency, and growth, Journal of International Business Studies 40, 1533-1562. 
Engelberg J., A. V. Reed, and M. Ringgenberg, 2012, How are shorts informed? short sellers, news, and information processing, Journal of Financial Economics 105, 260-278.

Fama, E. F. and K. R. French, 1993, Common risk factors in the return on bonds and stocks, Journal of Financial Economics 33, 3-53.

Ferreira, M. and P. Matos, 2008, The colors of investors' money: the role of institutional investors around the world Journal of Financial Economics 88, 499-533.

Gopalan, R.,O. Kadan,and M. Pevzner, 2012, Asset liquidity and stock liquidity, Journal of Financial and Quantitative Analysis 47, 333-364

Green, T.C., 2004, Economic news and the impact of trading on bond prices, Journal of Finance 59, 1201-1233.

Griffin, J., N. Hirschey, and P. Kelly, 2011, How important is the financial media in global markets? Review of Financial Studies, 24, 3941-3992.

Hameed, A, W. Kang, S. Viswanathan,2010, Stock market declines and liquidity, Journal of Finance 65, 257-293.

Haw, I., B. Hu, J.J. Lee, and W. Wu 2012, Investor protection and price informativeness about future earnings: international evidence, Review of Accounting Studies 17, 389-419.

Hong, H. and M. Kacperczyk, 2009, The price of sin: the effects of social norms on markets, Journal of Financial Economics 93, 15-36.

Hong, H., and J. C. Stein, 2003, Differences of opinion, short-sales constraints, and market crashes, Review of Financial Studies 16, 487-525.

Ince, O. S., and Porter, R. B., 2006, Individual equity return data from Thomson Datastream: Handle with care!, Journal of Financial Research 29, 463-479.

Jensen, M.,1968, The performance of mutual funds in the period 1945-1964, Journal of Finance 23, 389-416.

Jin, L. and S. Myers, 2006, R-square around the world: new theory and new tests, Journal of Financial Economics 79, 257-92.

Kacperczyk, M. and A. Seru, 2007, Fund manager use of semi-public information, Journal of Finance 52, 485-528

Kandel, E.,Pearson,N.,1995, Differential interpretation of public signals and trade in speculative markets, Journal of Political Economy103, 831-872.

Karolyi, G. A., Lee, K., and Van Dijk, M. A., 2012, Understanding commonality in liquidity sround the world, Journal of Financial Economics 105, 82-112.

Karolyi, G. A., and Wu, Y., 2012, The Role of investability restrictions on size, value, and momentum in international stock returns, working paper.

Kim O. and R.E. Verrecchia,1994, Liquidity and volume around earnings announcements, Journal of Accounting and Economics $17,41-67$.

Krinsky, I and J. Lee, 1996, Earnings announcements and the components of the bid-ask spread, Journal of Finance 51, 1523-1535.

Kyle, A. S., 1985, Continuous auctions and insider trading, Econometrica, 53, 1315-1335.

Lau, S. T.,L. Ng, and B. Zhang, 2010, The world price of home bias, Journal of Financial Economics 97, 191-217

Lee, C., B. Mucklow, and M. Ready,1993, Spreads, depths, and the impact of earnings information: an intraday analysis, Review of Financial Studies 6,345-374.

Madureira, L. and S. Underwood, 2008, Information, sell-side research, and market making, Journal of Financial Economics 90, 105-126.

Morck, R., B. Yeung, and W. Yu, 2000, The information content of stock markets: Why do emerging markets have synchronous stock price movements? Journal of Financial Economics 59, 215-260.

Opp, M.M., 2012, Expropriation risk and technology. Journal of Financial Economics, 103, 113-129.Pagano, M and P Volpin, 2012, Securitization, transparency, and liquidity, Review of Financial Studies 25, 2417-2453.

Petersen, M., 2009, Estimating standard errors in finance panel data sets: comparing approaches, Review of Financial Studies 22, 435-480. 
Sarkar, A and R.A. Schwartz, 2009, Market sidedness: insights into motives for trade initiation, Journal of Finance 64, 375-423.

Williamson, O., 1975, Markets and hierarchies: Analysis and Antitrust Implications (Free Press, New York).

Williamson, O., 1985, The economic institutions of capitalism (Free Press, New York).

Wurgler, J. A., 2000, Financial markets and the allocation of capital, Journal of Financial Economics 58, 187-214.

Xu, N., Kam C. C., X. Jiang and Z. Yi, 2013 Do star analysts know more firm-specific information? Evidence from China, Journal of Banking \& Finance 37,89-102 


\section{Appendix A: Summary of the Model}

This appendix extends Kim and Verrecchia (1994, hereafter, KV) based on a simple additional assumption that, in economies with weaker country-level governance, what the market knows about a firm (, public news) could be further away from the reality. KV assumes that a firm generates cash flows in each of the $\mathrm{T}$ periods of an economy. These cash flows are accumulated to the end and generate a liquidating value of $\widetilde{U}=\sum_{s=1}^{T} \tilde{u}_{s}$, where $\tilde{u}_{s}$ is the cash flow generated by the firm in period $s-$ it is known to the public by the end of the period. Now consider one specific period, $t$, before which the firm announces a public signal about the value of $\tilde{u}_{t}$ as $\tilde{Y}=\tilde{u}_{t}+\tilde{\delta}$, where $\tilde{\delta}$ is a noise. Assume that $\tilde{u}_{t} \sim N(0, a)$ and $\tilde{\delta} \sim N(0, d)$ are the unconditional distributions of the two variables.

Next, the announcement can be processed with different levels of precision by different types of investors. One type of investor, e.g., professional managers, can choose to pay a $\operatorname{cost} C$ to obtain a second signal (e.g., judgments) to fine tune the firm's public signal. There are $N$ such investors (the number is determined endogenously), and the $i^{\text {th }}$ investor observes (at a cost $C$ ): $\tilde{O}_{i}=\tilde{\delta}+\tilde{\epsilon}_{i}$, where $\tilde{\epsilon}_{i} \sim N(0, e)$ is a noise. The additional signal is referred to as semi-public information in this paper to differentiate it from both the public signal and real insider information (KV refers to it as the private signal). These investors also have incentives to trade in period $t$ (and only in this period).

The KV model further assumes that there are two types of liquidity traders. There are $L$ nondiscretionary liquidity traders who trade in each period. There are also $T M$ discretionary liquidity traders who can decide when to trade (but they do not observe information). In each period, the three types of investors submit trading demands, which allows a risk neutral market maker to update the market price. The summation of orders for period $t$ can be denoted as $\omega=x+z_{n}+z_{d}$, where $x=\sum_{i=1}^{N} x_{i}$ is the summation of orders from the $\mathrm{N}$ informed investors ( $x_{i}$ is the individual order), and $z_{n}$ and $z_{d}$ are similar summations of orders from nondiscretionary and discretionary investors, respectively.

Based on these assumptions, the informed investors trade following the Kyle (1985) model, which leads to an equilibrium for period $t$ that can be characterized as follows:

$$
x_{i}=\beta \tilde{Y}+\gamma \tilde{O}_{i}, \quad P_{t}=U_{t-1}+\alpha \tilde{Y}+\lambda \omega_{t},
$$

where $\alpha=\frac{a}{a+d}, \lambda=\sqrt{\frac{N a^{2} d^{2}(a d+a e+d e)}{v(a+d)[(N+1) a d+\{2+(N-1) \rho\} e(a+d)]^{2}}}, \beta=\sqrt{\frac{v d^{2}}{N(a+d)(a d+a e+d e)}}$, and $\gamma=-\sqrt{\frac{v(a+d)}{N(a d+a e+d e)}}$ are constants, and $v$ is the variance of the nondiscretionary liquidity traders. Note that informed traders only participate in this period of trading when they have semi-public information. Discretionary liquidity traders will not participate in this period because they will lose money by trading against the informed investors in the market. They will participate in trading in other periods. Hence, liquidity decreases in this particular period when informed investors can process information. Furthermore, 
volatility and the level of informativeness of the stock will increase because informed trading moves the price. Trading volume may increase or decrease (compared with other periods), depending on the mass of the discretionary and informed traders. Finally, the optimal number of informed traders is determined by information costs and the benefit of informed trading.

What could be the impact of country-level weak governance? Intuitively, it implies a gap between what firms in the economy claim about their cash flows and what the reality might be. The gap can be captured by the conditional variance of the cash flow value based on the public announcement. That is, if we denote $\sigma \equiv \operatorname{var}\left(\tilde{u}_{t} \mid \tilde{Y}\right)$ and $h \equiv 1 / \sigma$ as the conditional variance and precision based on the public announcement of the firms, and if we further denote $G$ as country-level governance with a higher value corresponding to a weak governance, then we can summarize the impact of weak governance as $\frac{\partial \sigma}{\partial G}>0$ or $\frac{\partial h}{\partial G}<0$. It is easy to verify that $\sigma=a d /(a+d)$. That is, a larger gap between the announcement and reality might come from two economic sources related to countrylevel governance. First, cash flows are more risky in countries with weaker governance $\left(, \frac{\partial a}{\partial G}>0\right)$ because the weaker governance might imply some additional exploitation risk to affect the normal cash flows that can be generated by the normal business of firms (e.g., Opp, 2012). Second, firms in bad countries may make poor announcements $\left(, \frac{\partial d}{\partial G}>0\right)$ because managers may find it optimal and easy to hide information in such an environment (Morck, Yeung and Yu, 2000, Jin and Myers, 2006, DeFond, Hung, and Trezevant, 2007, Haw et al. 2012, Bartram, Brown, and Stulz, 2012). In both cases, public information in poor governance countries becomes less accurate than in countries with good governance. Because firms invest less in firm-level governance in countries with poor country-level governance (Doidge, Karolyi, and Stulz, 2007), these problems are unlikely to be solved by corporate governance.

The impact of country-level governance can be summarized in the following proposition.

Proposition 1: In the presence of weak country-level governance, the equilibrium described above will further demonstrate the following properties related to governance:

1) Informed investors use more of their semi-public signal and less public information in countries with bad governance. Mathematically, $\frac{\beta^{2}}{\beta^{2}+\gamma^{2}}$ decreases in $G$ (or $\frac{\gamma^{2}}{\beta^{2}+\gamma^{2}}$ increases in $G$ ). Furthermore, trading variation also relies more on the semi-public signal than on public information in countries with weak governance, i.e., $\frac{\gamma^{2} \operatorname{var}\left(\tilde{O}_{i}\right)}{\beta^{2} \operatorname{var}(\tilde{Y})}$ increases in $G$.

2) More informed investors will optimally emerge to exploit private information $\left(, \frac{d N}{d G}>0\right)$ in countries with weak governance.

3) The stock becomes less liquid in countries with weak governance, 
4) The stock price becomes more volatile and more informative in countries with weak governance.

Proof: 1): Plugging parameter values, we obtain $\frac{\beta^{2}}{\beta^{2}+\gamma^{2}}=\frac{d^{2}}{d^{2}+(a+d)^{2}}=\frac{1}{1+a^{2} \sigma^{2}}$. Thus, $\frac{d}{d G}\left(\frac{\beta^{2}}{\beta^{2}+\gamma^{2}}\right)=$ $\frac{\partial\left(\frac{\beta^{2}}{\beta^{2}+\gamma^{2}}\right)}{\partial a} \times \frac{d a}{d G}+\frac{\partial\left(\frac{\beta^{2}}{\beta^{2}+\gamma^{2}}\right)}{\partial \sigma} \times \frac{d \sigma}{d G}<0$. It is trivial to obtain the positive sign for $\frac{d}{d G}\left(\frac{\gamma^{2}}{\beta^{2}+\gamma^{2}}\right)$. Meanwhile, $\frac{\gamma^{2} \operatorname{var}\left(\tilde{O}_{i}\right)}{\beta^{2} \operatorname{var}(Y)}=\frac{(a+d)^{2} \times(d+e)}{d^{2} \times(a+d)}=\frac{(a+d)(d+e)}{d^{2}}=a \sigma e \times \operatorname{var}\left(\tilde{\delta} \mid \tilde{O}_{i}\right)$. It is easy to see that $a \sigma$ increases in weak governance. To the extent that $\operatorname{var}\left(\tilde{\delta} \mid \tilde{O}_{i}\right)$ is indeterminate because weak governance may or may not allow managers to collect more precise private information, the overall ratio increases in weak governance.

2, 3, and 4): KV proves that less precise public information (, a larger $\sigma$ ) allows more informed traders to optimally process private information (Lemma 1), less precise public information reduces liquidity (proposition 1), and less precise public information enhances volatility and informativeness (Propositions 3 and 4). The chain law leads to our results. For instance, because $\frac{d N}{d \sigma}>0$, we have $\frac{d N}{d G}=\frac{d N}{d \sigma} \times \frac{d \sigma}{d G}>0$. Similarly, $\frac{d \Delta}{d \sigma}>0$ and $\frac{d F}{d \sigma}>0$, where $\Delta$ is the volatility of the price change and $F$ denotes the reduction in the variance of $\tilde{u}_{t}$ once the stock price is updated by informed trading. Both are positive because informed trading affects the stock price in A1 by incorporating more accurate information about the cash flow. Our economic intuition is that less precise public information induced by weak governance makes it more profitable for managers to process semi-public information. Therefore, these markets should exhibit more informed trading, thus reducing liquidity and enhancing volatility and price informativeness.

Note that trading volume becomes indeterminate in our model. This is because there are no economic reasons to believe that weak governance will change the mass of discretionary liquidity traders relative to that of potentially informed traders, which is a key determinant in trading volume.

Overall, our extension posits a unique role for financial intermediaries to affect asset pricing induced by weak country-level governance: the lack of accurate public information provides incentives for them to process their own semi-public information. Their trading, consequently, increases the informativeness of the price while reducing liquidity. 


\section{Appendix B: Variable Definitions}

\section{Horizontal and Vertical Governance Variables}

(We normalize the value of all governance variables with 1 for the weakest governance and 0 for the best governance.)

Legal Formalism: Index of formality in legal procedures for collecting on a bounced check; ranges from 1 to 7.

Procedural Complexity: Index of complexity in collecting a commercial debt, valued at 50\% of annual GDP per capita; ranges from 0 to 10 .

Number of Procedures: Number of procedures involved in collecting a commercial debt, valued at 50\% of annual GDP per capita.

Executive Constraints: A seven-category scale, from 1 to 7, with a higher score indicating more constraint.

Protection Expropriation: Risk of expropriation of private foreign investment, from 0 to 10, with a higher score meaning less risk.

Private Property: From 1 to 5, with a higher score indicating better protection for private property.

Horizontal Gov: average of normalized Legal Formalism, Procedural Complexity and Number of Procedures.

Vertical Gov: average of normalized Executive Constraints, Protection Expropriation and Private Property.

\section{Alternative Governance Variables}

(We normalize the value of all governance variables with one for the weakest governance and 0 for the best governance.)

Poor Gov: The reverse of the good government index from Karolyi, Lee, and van Dijk (2012). The good government index is defined as the sum of the following three indices from the International Country Risk Guide (each ranging from zero to ten): (i) government corruption, (ii) the risk of expropriation of private property by the government, and (iii) the risk of the government repudiating contracts. Lower scores for each index indicate less respect for private property.

Disclosure: Assessment of the prevalence of disclosures concerning research and development (R\&D) expenses, capital expenditures, product and geographic segment data, subsidiary information, and accounting methods based on the 1995 International Accounting and Auditing Trends from the Center for Financial Analysis and Research (CIFAR). The source is Bushman, Piotroski, and Smith (2004).

Anti_SD: The anti-self-dealing index of Djankov, La Porta, Lopez-de-Silanes and Shleifer (2008).

Acc Transparency: Accounting transparency from Durnev, Errunza and Molchanov (2009).

CPI: Corruption Perceptions Index published by Transparency International. The CPI defines corruption as the misuse of public power for private benefit. Every year, it ranks countries on a scale from 10 (very clean) to 0 (highly corrupt). ). We reverse and scale the index so that $C P I$ ranges from 0 (very clean) to 1 (highly corrupt).

Measures on the Use of Semi-public and Public Information

Fund SemPub_Poor: Partial R-square of the $\gamma_{k, t} \Delta R e_{i, t} \times G_{i}$ term from regression of Equation (1).

Fund SemPub_Good: Partial R-square of $\gamma_{k, t} \Delta R e_{i, t}$ term from regression of Equation (1).

Fund Pub_Poor: Partial R-square of the $\gamma_{k, t}^{N} \Delta N S_{i, t} \times G_{i}$ term.

Fund Pub_Good: Partial R-square of the $\lambda_{k, t}^{N} \Delta \mathrm{NS}_{i, t}$ term.

SemPub_Poor: Value-weighted average of Fund SemPub_Poor of funds investing in the stock, weighted by their investment values.

SemPub_Good: Value-weighted average of Fund SemPub_Good of funds investing in the stock, weighted by their investment values.

Pub_Poor: Value-weighted average of Fund Pub_Poor of funds investing in the stock, weighted by their investment values.

Pub_Good: Value-weighted average of Fund Pub_Good of funds investing in the stock, weighted by their investment values.

\section{Mutual Fund Characteristics}

ExpenseRatio: Expense Ratio of mutual funds.

Turnover: Funds' turnover.

FundSize: The natural log of 1 plus the fund's last period`s total net asset.

\section{Stock Characteristics}

Amihud Illiquidity(Illiq): We first define a monthly Amihud illiquidity measure for each stock as Illiq $q_{t}=\ln \left(1+\sum_{d} \frac{|r|}{v}\right)$, where $r$ is the daily return, $v$ is the daily dollar trading volume, and $d$ is the number of trading days in month $t$. Following the spirit of Chordia, Sarkar, and Subrahmanyam (2005), Hameed, Kang, and Viswanathan (2010), and Karolyi, Lee and van Dijk (2012), we further adjust for seasonality by running regressions for each stock $i$ based on observations on month $t:$ Illiq $_{i, t}=\beta_{m} \sum_{m=1}^{11} D_{m}+\varepsilon_{i, t}$, where $D_{m}$ is the dummy variable that takes the value of one for calendar months from 
Feb to Dec $m$ and zero otherwise. We use the residuals $\varepsilon_{i, t}$ from the regression to obtain monthly measures of Amihud illiquidity. Note that these papers typically also control for day-of-the-week and holiday effects for daily liquidity. Since these daily controls are less relevant to our semi-annual variables, we focus on calendar month adjustments. We then compute semi-annual Amihud illiquidity as the average value of monthly illiquidity within the semi-annual period.

Zero Return: Percentage of zero return days for a stock during the semi-annual (six-month) period.

Idiosyncratic Volatility(Idiosyncratic Vol): We define idiosyncratic volatility as the standard deviation of the residuals from the daily Fama-French regression in a given semi-annual period. We then transform idiosyncratic volatility by adding 1 and taking the log transformation. We follow Bartram et al. (2012) and Bekaert, Hodrick, and Zhang (2012) use two versions of models. In the first version, we use three domestic Fama-French factors and three international factors. In the second version, we use the market and industry factors.

Raw Return: average monthly stock return during the semi-annual period.

DGTW Return: Following Daniel, Grinblatt, Titman, and Wermers (1997), we create 125 style benchmarks based on the size, book-to-market, and prior-period return characteristics of all the stocks within each country. We then compute the monthly DGTW-adjusted return for each stock as the stock return minus the return of the matching style benchmark in the same month. When applicable, we compute the semi-annual DGTW return as the average monthly DGTW return of the stock in the semi-annual period.

Market to Book (M/B): Market Value of Equity/ Book EquityTobin's Q: ((Total Assets-Book Equity)+Market Value of Equity)/Total Assets.

BM: Book Equity/Market Value of Equity.

IO: Institutional ownership.

Logsize: Log of stock market value.

MOM: Cumulative returns from the previous 6 months.

$\boldsymbol{R O E}$ : Return on equity, the ratio of earnings during year $\mathrm{t}$ over the book value of equity at the end of year $t$.

FROE, F2ROE: The next two (semi-annual) period's ROEs.

Flow_Std: The standard deviation of stock-level fund flow in the six-month period. Stock-level fund flow is defined as fund flows weighted by the fraction of outstanding shares invested by funds.

Changes in Analyst Recommendation ( $\Delta \boldsymbol{R e}$ ): We reverse the rating (let rating $=6$ - raw rating) such that a positive $\Delta \mathrm{Re}$ means an upgrade in analyst recommendation.

Leverage: Total debt divided by equity

Cash/TA: Ratio of cash and cash equivalents to lagged total assets. CapEx: Capital expenditures, defined as the ratio of a firm's capital expenditures to lagged total assets. When the data are missing, this variable is set to zero.

R\&D: Research and development expenditure as a percentage of total sales.

$\boldsymbol{R O A}$ : Ratio of earnings before depreciation, interest, and taxes over lagged value of total assets.

Firm Gov: The firm governance index from Aggarwal, Erel, Ferreira and Matos, 2011, which is the percentage of the 41 governance attributes that a firm meets. We normalize the value with one for the weakest governance and 0 for the best governance).

PPE/TA: Total property, plant, and equipment (net) divided by total assets

Age(log): Difference between year of observation and year of first listing +1 .

Debt maturity: Total long-term debt (due in more than 1 year) divided by total debt.

\section{Other Country Level control Valuables}

ICRG political risk index: Index measures the overall stability and quality of government institutions using 10 different qualitative measures such as internal and external conflict, corruption, law and order, and bureaucratic quality. Higher values represent more stable and higher quality government institutions. Data are from the PRS group

Creditor rights: From Djankov, McLiesh, and Shleifer (2007).

Anti-director rights: From Andrei Shleifer's website. Revised index as described in Djankov et al. (2008).

Stock market turnover: Ratio of annual trading volume to shares outstanding. Data are from the World Bank.

Stock market Capit. (\%GDP): Ratio of end-of-year stock market capitalization to nominal GDP. Data are from the World Bank.

Private bond market (\%GDP): Private domestic debt securities issued by financial institutions and corporations as a share of GDP. Data are from the World Bank Financial Development and Structure Database.

Equity market liberalization: The percentage of the equity market that is investable for foreign investors. Data are fron EMDB. 


\section{Appendix C. Sample Selection}

This table shows the procedure for how we construct our final sample from the following main datasets: Datastream/WorldScope, CRSP/Compustat, FactSet/LionShares, Morningstar international and IBES. We report the total number of stocks for each step.

\begin{tabular}{lc}
\hline Procedure & Number of stocks \\
\hline Common stocks from Datastream/WorldScope and & 45,343 \\
CRSP/Compustat for the time period 1999-2009 & 34,839 \\
Merging with mutual fund holding data from FactSet/LionShares & 23,045 \\
Merging with fund information from Morningstar International & 23,045 \\
Merging with I/B/E/S & 21,329 \\
Merging with the main measures of governance from & 16,313 \\
Acemoglu and Johnson (2005) & \\
Other screen procedures: & \\
Stocks with at least 12 monthly returns, at least 12 months of no & \\
missing trading volume and with a price greater than U\$ 1 & \\
\hline
\end{tabular}




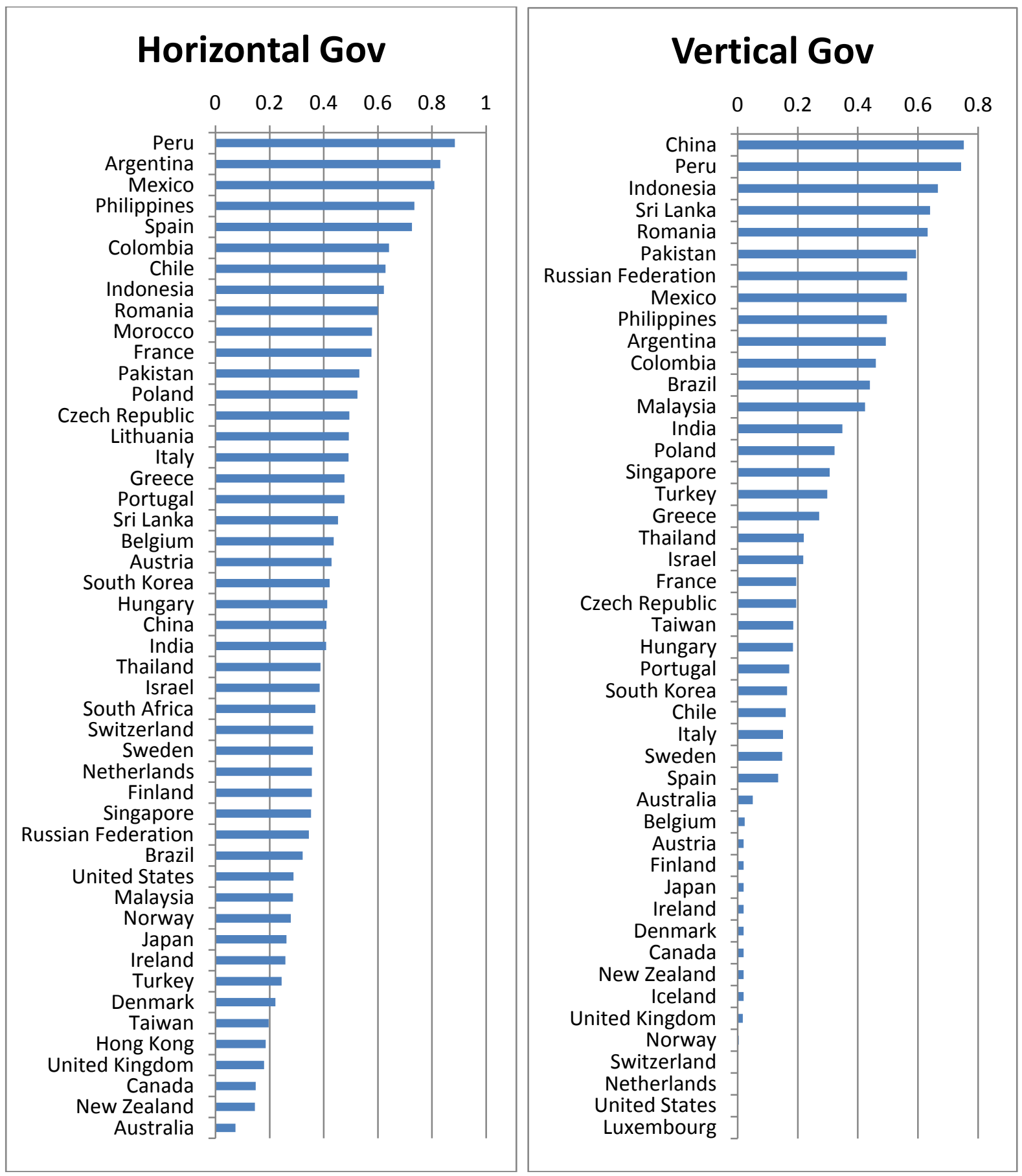

Fig. 1. Governance index by country. This figure shows the horizontal (contracting) and vertical (property rights) governance index by country. A larger index value indicates a worse governance practice in our sample. 
Table 1: Descriptive Statistics

Panel A reports summary statistics of our sample stocks over the 2000-2009 period. The sample selection procedure is described in Appendix C. We also apply several screening procedures for Datastream data errors in monthly returns as suggested by Ince and Porter (2006) and others. Panel $\mathrm{B}$ reports the correlation matrix of the main variables. Panel $\mathrm{C}$ reports the correlation matrix of the governance proxies. All the variables are described in Appendix B.

\begin{tabular}{|c|c|c|c|c|c|c|c|c|c|c|c|c|c|c|c|c|}
\hline \multicolumn{17}{|c|}{ Panel A: Distributions } \\
\hline & \multicolumn{6}{|c|}{ Whole Sample Distribution } & \multicolumn{10}{|c|}{ Quintile Distribution by Horizontal $(\mathrm{H})$ and Vertical (V) Governance Indices } \\
\hline & $\mathrm{N}$ & Mean & $\begin{array}{c}\text { Std } \\
\text { Dev }\end{array}$ & MIN & Median & MAX & H1 & $\mathrm{H} 2$ & H3 & H4 & H5 & V1 & V2 & V3 & V4 & V5 \\
\hline \multicolumn{17}{|c|}{ Asset Pricing Characteristics of Stocks } \\
\hline Zero Return & 135629 & 0.058 & 0.105 & 0 & 0.016 & 0.581 & 0.018 & 0.049 & 0.091 & 0.038 & 0.118 & 0.018 & 0.027 & 0.107 & 0.073 & 0.096 \\
\hline $\begin{array}{l}\text { Idiosyn Vol (from } 6 \text { factor } \\
\text { model) } \\
\text { Idiosyn Vol (from market and }\end{array}$ & 135621 & 0.022 & 0.011 & 0.008 & 0.020 & 0.065 & 0.019 & 0.019 & 0.021 & 0.017 & 0.02 & 0.02 & 0.018 & 0.019 & 0.019 & 0.02 \\
\hline industry factor model) & 135642 & 0.021 & 0.011 & 0.004 & 0.019 & 0.066 & 0.018 & 0.019 & 0.020 & 0.017 & 0.018 & 0.020 & 0.018 & 0.019 & 0.018 & 0.018 \\
\hline RET & 135641 & 0.011 & 0.059 & -1 & 0.012 & 1.278 & 0.014 & 0.014 & 0.018 & 0.009 & 0.016 & 0.01 & 0.009 & 0.013 & 0.016 & 0.024 \\
\hline DGTW & 135641 & 0.001 & 0.042 & -0.151 & 0.001 & 0.115 & 0.004 & 0.007 & 0.008 & -0.004 & 0.008 & 0.002 & 0.002 & 0.003 & 0.008 & 0.013 \\
\hline $\mathrm{M} / \mathrm{B}$ & 118854 & 2.31 & 1.65 & 0.36 & 1.8 & 11.22 & 2.009 & 1.809 & 1.985 & 2.188 & 2.207 & 2.063 & 1.925 & 1.745 & 1.967 & 2.429 \\
\hline Tobin`s q & 135642 & 1.39 & 0.79 & 0.58 & 1 & 7.82 & 1.539 & 1.337 & 1.506 & 1.532 & 1.559 & 1.365 & 1.403 & 1.358 & 1.383 & 1.79 \\
\hline \multicolumn{17}{|c|}{ Public and Semi-public Information for Stocks } \\
\hline \# Analyst Per Stock & 167269 & 8.74 & 7.97 & 1.00 & 6.00 & 74.00 & 13 & 16 & 16 & 14 & 12 & 21 & 18 & 18 & 10 & 8 \\
\hline$\%$ Analyst Coverage & 50 & $64 \%$ & $20 \%$ & $13 \%$ & $66 \%$ & $100 \%$ & 0.70 & 0.76 & 0.67 & 0.61 & 0.61 & 0.77 & 0.69 & 0.67 & 0.70 & 0.55 \\
\hline $\operatorname{Re}$ & 167269 & 3.63 & 0.70 & 1.00 & 3.67 & 5.00 & 3.59 & 3.49 & 3.57 & 3.39 & 3.44 & 3.58 & 3.46 & 3.47 & 3.51 & 3.52 \\
\hline Standardized $\Delta \mathrm{Re}$ & 165162 & -0.05 & 0.60 & -6.46 & -0.03 & 6.05 & -0.02 & -0.03 & -0.03 & -0.04 & -0.02 & -0.02 & -0.03 & -0.03 & -0.02 & -0.04 \\
\hline \# News Per Stock & 119499 & 76.52 & 219.60 & 1 & 37 & 12322 & 21.21 & 19.53 & 17.63 & 14.78 & 14.43 & 31.88 & 21.97 & 18.30 & 15.18 & 14.28 \\
\hline$\%$ News Coverage & 119499 & 49.55 & 3.14 & 4.00 & 50.00 & 100.00 & $68 \%$ & $59 \%$ & $61 \%$ & $59 \%$ & $60 \%$ & $64 \%$ & $75 \%$ & $67 \%$ & $50 \%$ & $52 \%$ \\
\hline NS & 115727 & -0.10 & 3.52 & -56.00 & -0.01 & 66.50 & 50.3 & 49.8 & 49.6 & 49.0 & 50.1 & 49.7 & 49.9 & 49.6 & 49.8 & 50.4 \\
\hline$\Delta \mathrm{NS}$ & 115723 & -0.06 & 4.30 & -58 & 0 & 66.5 & -0.04 & -0.10 & -0.09 & -0.32 & 0.46 & 0.18 & -0.01 & -0.26 & -0.14 & 0.66 \\
\hline Standardized $\Delta \mathrm{NS}$ & 115723 & -0.01 & 0.78 & -10.18 & 0.00 & 14.28 & 0.003 & 0.001 & -0.005 & -0.009 & -0.002 & 0.009 & -0.025 & 0.008 & 0.015 & -0.032 \\
\hline \multicolumn{17}{|l|}{ Use of Information } \\
\hline$\% \Delta$ Hold $_{i, k, t}$ & 26670717 & -2.21 & 73 & -100 & -3.13 & 100 & -2.66 & -2.74 & 1.32 & -7.70 & 1.09 & -2.68 & -2.30 & -1.98 & -0.83 & -1.73 \\
\hline Fund Horizontal SemPub_Poor & 93388 & 0.033 & 0.078 & 0.000 & 0.008 & 0.966 & 0.045 & 0.028 & 0.024 & 0.067 & 0.045 & 0.029 & 0.042 & 0.025 & 0.038 & 0.016 \\
\hline Fund Vertical SemPub_Poor & 92899 & 0.033 & 0.077 & 0.000 & 0.008 & 0.962 & 0.045 & 0.029 & 0.036 & 0.062 & 0.045 & 0.030 & 0.040 & 0.026 & 0.058 & 0.027 \\
\hline Fund SemPub_Good & 104579 & 0.038 & 0.085 & 0.000 & 0.012 & 0.979 & 0.051 & 0.043 & 0.045 & 0.046 & 0.045 & 0.036 & 0.047 & 0.044 & 0.049 & 0.033 \\
\hline Horizontal SemPub_Poor & 128922 & 0.011 & 0.022 & 0 & 0.005 & 0.512 & 0.0068 & 0.0095 & 0.0081 & 0.0118 & 0.0078 & 0.0086 & 0.0085 & 0.0096 & 0.0069 & 0.0096 \\
\hline Vertical SemPub_Poor & 128904 & 0.011 & 0.023 & 0 & 0.005 & 0.525 & 0.0069 & 0.0098 & 0.0086 & 0.0118 & 0.0085 & 0.0090 & 0.0086 & 0.0100 & 0.0078 & 0.0104 \\
\hline SemPub_Good & 134618 & 0.017 & 0.023 & 0 & 0.011 & 0.426 & 0.0105 & 0.0137 & 0.0125 & 0.0236 & 0.0108 & 0.0133 & 0.0133 & 0.0159 & 0.0103 & 0.0132 \\
\hline
\end{tabular}




\begin{tabular}{|c|c|c|c|c|c|c|c|c|c|c|c|}
\hline & & & Panel B: C & relation mat & $\mathrm{x}$ for $\mathrm{Se}$ & $b$ measur & d stock & teristics & & & \\
\hline & $\begin{array}{l}\text { Amihud } \\
\text { Illiqudity }\end{array}$ & $\begin{array}{l}\text { Zero } \\
\text { Return }\end{array}$ & $\begin{array}{l}\text { Idiosyn } \\
\text { Vol (from } \\
\text { market and } \\
\text { industry } \\
\text { model) }\end{array}$ & $\begin{array}{l}\text { Idiosyn } \\
\text { Vol(from } 6 \\
\text { factor } \\
\text { model) }\end{array}$ & RET & $\begin{array}{l}\text { DGTW } \\
\text { Return }\end{array}$ & $\mathrm{M} / \mathrm{B}$ & Tobin`s Q & $\begin{array}{l}\text { Horizontal } \\
\text { SemPub_Poor }\end{array}$ & $\begin{array}{l}\text { Vertical } \\
\text { SemPub_Poor }\end{array}$ & SemPub_Good \\
\hline Amihud Illiquidity & 1 & $\begin{array}{l}0.071 \\
(0.00)\end{array}$ & $\begin{array}{l}0.008 \\
(0.00)\end{array}$ & $\begin{array}{l}0.048 \\
(0.00)\end{array}$ & $\begin{array}{l}-0.049 \\
(0.00)\end{array}$ & $\begin{array}{l}-0.032 \\
(0.00)\end{array}$ & $\begin{array}{l}-0.093 \\
(0.00)\end{array}$ & $\begin{array}{l}0.001 \\
(0.76)\end{array}$ & $\begin{array}{l}0.036 \\
(0.00)\end{array}$ & $\begin{array}{l}0.039 \\
(0.00)\end{array}$ & $\begin{array}{l}0.025 \\
(0.00)\end{array}$ \\
\hline Zero Return & & 1 & $\begin{array}{l}0.15 \\
(0.00)\end{array}$ & $\begin{array}{l}0.093 \\
(0.00)\end{array}$ & $\begin{array}{l}-0.02 \\
(0.09)\end{array}$ & $\begin{array}{l}-0.034 \\
(0.00)\end{array}$ & $\begin{array}{l}-0.084 \\
(0.00)\end{array}$ & $\begin{array}{l}-0.069 \\
(0.00)\end{array}$ & $\begin{array}{l}0.012 \\
(0.31)\end{array}$ & $\begin{array}{l}0.008 \\
(0.49)\end{array}$ & $\begin{array}{l}0.01 \\
(0.38)\end{array}$ \\
\hline $\begin{array}{l}\text { Idiosyn Vol (from market } \\
\text { and industry model) }\end{array}$ & & & 1 & $\begin{array}{l}0.899 \\
(0.00)\end{array}$ & $\begin{array}{l}0.073 \\
(0.00)\end{array}$ & $\begin{array}{l}0.05 \\
(0.00)\end{array}$ & $\begin{array}{l}0.074 \\
(0.00)\end{array}$ & $\begin{array}{l}0.088 \\
(0.00)\end{array}$ & $\begin{array}{l}0.026 \\
(0.03)\end{array}$ & $\begin{array}{l}-0.003 \\
(0.82)\end{array}$ & $\begin{array}{l}0.046 \\
(0.00)\end{array}$ \\
\hline $\begin{array}{l}\text { Idiosyn Vol (from } 6 \text { factor } \\
\text { model) }\end{array}$ & & & & 1 & $\begin{array}{l}0.084 \\
(0.00)\end{array}$ & $\begin{array}{l}0.06 \\
(0.00)\end{array}$ & $\begin{array}{l}0.083 \\
(0.00)\end{array}$ & $\begin{array}{l}0.101 \\
(0.00)\end{array}$ & $\begin{array}{l}0.026 \\
(0.03)\end{array}$ & $\begin{array}{l}0.008 \\
(0.51)\end{array}$ & $\begin{array}{l}0.044 \\
(0.00)\end{array}$ \\
\hline RET & & & & & 1 & $\begin{array}{l}0.919 \\
(0.00)\end{array}$ & $\begin{array}{l}0.174 \\
(0.00)\end{array}$ & $\begin{array}{l}0.173 \\
(0.00)\end{array}$ & $\begin{array}{l}-0.013 \\
(0.29)\end{array}$ & $\begin{array}{l}-0.01 \\
(0.42)\end{array}$ & $\begin{array}{l}-0.008 \\
(0.53)\end{array}$ \\
\hline DGTW Return & & & & & & 1 & $\begin{array}{l}0.237 \\
(0.00)\end{array}$ & $\begin{array}{l}0.233 \\
(0.00)\end{array}$ & $\begin{array}{l}-0.008 \\
(0.52)\end{array}$ & $\begin{array}{l}-0.004 \\
(0.73)\end{array}$ & $\begin{array}{l}0.005 \\
(0.71)\end{array}$ \\
\hline $\mathrm{M} / \mathrm{B}$ & & & & & & & 1 & $\begin{array}{l}0.903 \\
(0.00)\end{array}$ & $\begin{array}{l}-0.011 \\
(0.29)\end{array}$ & $\begin{array}{l}-0.016 \\
(0.12)\end{array}$ & $\begin{array}{l}0.084 \\
(0.00)\end{array}$ \\
\hline Tobin`s Q & & & & & & & & 1 & $\begin{array}{l}-0.014 \\
(0.16)\end{array}$ & $\begin{array}{l}-0.019 \\
(0.06)\end{array}$ & $\begin{array}{l}0.088 \\
(0.00)\end{array}$ \\
\hline Horizontal SemPub_Poor & & & & & & & & & 1 & $\begin{array}{l}0.622 \\
(0.00)\end{array}$ & $\begin{array}{l}0.176 \\
(0.00)\end{array}$ \\
\hline Vertical SemPub_Poor & & & & & & & & & & 1 & $\begin{array}{l}0.18 \\
(0.00)\end{array}$ \\
\hline SemPub_Good & & & & & & & & & & & 1 \\
\hline
\end{tabular}

\begin{tabular}{|c|c|c|c|c|c|c|c|}
\hline \multicolumn{8}{|c|}{ Panel C: Correlation Matrix of Governance } \\
\hline \multirow{3}{*}{ Horizontal Gov } & Horizontal Gov & Vertical Gov & Poor Gov & Disclosure & Anti_SD & Acc Transparency & CPI \\
\hline & 1 & 0.59 & 0.58 & 0.2 & 0.46 & 0.16 & 0.6 \\
\hline & & $(0.00)$ & $(0.00)$ & $(0.25)$ & $(0.00)$ & $(0.29)$ & $(0.00)$ \\
\hline \multirow[t]{2}{*}{ Vertical Gov } & & 1 & 0.89 & 0.47 & 0.02 & 0.11 & 0.83 \\
\hline & & & $(0.00)$ & $(0.01)$ & $(0.88)$ & $(0.46)$ & $(0.00)$ \\
\hline \multirow[t]{2}{*}{ Poor Gov } & & & 1 & 0.58 & 0.11 & 0.34 & 0.91 \\
\hline & & & & $(0.00)$ & $(0.52)$ & $(0.04)$ & $(0.00)$ \\
\hline \multirow[t]{2}{*}{ Disclosure } & & & & 1 & 0.29 & 0.3 & 0.64 \\
\hline & & & & & $(0.09)$ & $(0.08)$ & $(0.00)$ \\
\hline \multirow[t]{2}{*}{ Anti_SD } & & & & & 1 & 0.06 & 0.15 \\
\hline & & & & & & $(0.70)$ & $(0.29)$ \\
\hline \multirow[t]{2}{*}{ Acc Transparency } & & & & & & 1 & 0.24 \\
\hline & & & & & & & $(0.10)$ \\
\hline CPI & & & & & & & 1 \\
\hline
\end{tabular}


Table 2: Governance and the Fund-level Use of Semi-public Information (First Stage Regression)

This table conducts the following regression for each fund in a semi-annual holding period,

$$
\% \Delta \text { Hold }_{i, k, t}=a_{k, t}+\lambda_{k, t}^{*} \Delta R e_{i, t}+\lambda_{k, t}^{G} G_{i}+\gamma_{k, t} \Delta R e_{i, t} \times G_{i}+c \times M_{i, t-1}+\varepsilon_{i, k, t},
$$

where $\% \Delta$ Hold $_{i, k, t}$ denotes the percentage rebalancing in split-adjusted holdings of stock $i$ held by fund $k$ over the semi-annual period, $\Delta R e_{i, t}$ is the change in the recommendation of the consensus analyst forecast of stock $i$, and $G_{i}$ is the governance index of the country of the stock. $\mathrm{M}_{\mathrm{i}, \mathrm{t}-1}$ stacks potential control variables, including country and industry return, and lagged analyst recommendation changes. The table reports the average value of the regression coefficients and the corresponding robust $t$-statistics. The superscripts ${ }^{* * *},{ }^{* *}$, and ${ }^{*}$ refer to the $1 \%, 5 \%$, and $10 \%$ levels of statistical significance, respectively. The sample includes fund-firm-semiannual observations over the 20002009 period.

\begin{tabular}{|c|c|c|c|c|c|c|}
\hline & 1 & 2 & 3 & 4 & 5 & 6 \\
\hline$\Delta \operatorname{Re}$ & $\begin{array}{l}12.587^{* * *} \\
(114.54)\end{array}$ & $\begin{array}{c}1.725^{* * *} \\
(3.96)\end{array}$ & $\begin{array}{c}10.383^{* * * *} \\
(67.54)\end{array}$ & $\begin{array}{l}14.124^{* * *} \\
(107.62)\end{array}$ & $\begin{array}{c}3.865^{* * *} \\
(6.83)\end{array}$ & $\begin{array}{c}11.628^{* * *} \\
(57.55)\end{array}$ \\
\hline$\Delta \operatorname{Re}(\mathrm{t}-1)$ & & & & $\begin{array}{l}6.078^{* * *} \\
(48.76)\end{array}$ & $\begin{array}{l}5.675^{* * *} \\
(44.01)\end{array}$ & $\begin{array}{l}5.633^{* * *} \\
(43.44)\end{array}$ \\
\hline Horizontal Gov & & $\begin{array}{l}-0.048 \\
(-0.08)\end{array}$ & & & $\begin{array}{c}-2.330^{* * * *} \\
(-3.23)\end{array}$ & \\
\hline$\Delta \mathrm{Re}^{*}$ Horizontal Gov & & $\begin{array}{c}30.434^{* * * *} \\
(26.54)\end{array}$ & & & $\begin{array}{c}27.069^{* * * *} \\
(18.99)\end{array}$ & \\
\hline Vertical Gov & & & $\begin{array}{l}-3.513^{*} \\
(-1.77)\end{array}$ & & & $\begin{array}{l}-0.486 \\
(-0.21)\end{array}$ \\
\hline$\Delta \mathrm{Re}^{*}$ Vertical Gov & & & $\begin{array}{c}25.608^{* * * *} \\
(9.37)\end{array}$ & & & $\begin{array}{c}26.521^{* * * *} \\
(7.53)\end{array}$ \\
\hline Market Return (t-1) & & & & $\begin{array}{c}66.733^{* * *} \\
(4.6)\end{array}$ & $\begin{array}{c}30.394^{* * * *} \\
(4.35)\end{array}$ & $\begin{array}{c}19.874^{\text {*** }} \\
(2.78)\end{array}$ \\
\hline Industry Return (t-1) & & & & $\begin{array}{c}61.302^{* * *} \\
(23.37)\end{array}$ & $\begin{array}{c}53.355^{* * * *} \\
(19.75)\end{array}$ & $\begin{array}{c}51.532^{* * *} \\
(19.1)\end{array}$ \\
\hline Constant & $\begin{array}{c}10.874 * * * \\
(125.57)\end{array}$ & $\begin{array}{c}11.759 * * * \\
(50.6)\end{array}$ & $\begin{array}{c}10.391 * * * \\
(96.09)\end{array}$ & $\begin{array}{l}8.674^{* * * *} \\
(35.34)\end{array}$ & $\begin{array}{c}10.299^{* * * *} \\
(29.94)\end{array}$ & $\begin{array}{l}9.093^{* * *} \\
(41.32)\end{array}$ \\
\hline \# Fund-Semiannual & 104957 & 104955 & 104939 & 104933 & 104927 & 104888 \\
\hline Avg R-square & 0.038 & 0.098 & 0.097 & 0.142 & 0.194 & 0.193 \\
\hline
\end{tabular}




\section{Table 3: Fund Performance and the Fund-level Use of Semi-public Information}

This table presents the panel regression analysis of the relationship between Fund SemPub_Poor and fund performance. We use the four-factor alpha of Carhart (1997) to measure fund performance based on a 36-month rolling window. More specifically, we estimate the factor loadings of funds based on the 36-month period prior to $t$, and then compute the performance of the fund in month $t$ as the difference between the realized fund return in month $t$ (in excess of the risk free rate) and the realized risk premium in the same month (i.e., the produc of the vector of rolling factor loadings times the realized factor return in month $t$ ). We average the monthly performance in a semi-annual period as the performance of the period. We then regress out-of-sample performance on the use of semi-public and public information induced by poor governance (Fund SemPub_Poor, Fund Pub_Poor) and a set of control variables in a panel specification with fixed country and time effects (we cluster the residuals by country and time). The fund control variables include the following: expense ratio, portfolio turnover, and fund size (defined in terms of total net assets). The superscripts ${ }^{* * *},{ }^{* *}$, and ${ }^{*}$ refer to $1 \%$, $5 \%$, and $10 \%$ levels of statistical significance, respectively. The sample includes fund-semiannual observations over the 2000-2009 period.

\begin{tabular}{|c|c|c|c|c|}
\hline & 1 & 2 & 3 & 4 \\
\hline & $\begin{array}{l}\text { Horizontal Fund } \\
\text { SemPub_Poor }\end{array}$ & $\begin{array}{l}\text { Vertical Fund } \\
\text { SemPub_Poor }\end{array}$ & $\begin{array}{l}\text { Horizontal Fund } \\
\text { SemPub_Poor }\end{array}$ & $\begin{array}{l}\text { Vertical Fund } \\
\text { SemPub_Poor }\end{array}$ \\
\hline Fund SemPub_Poor & $\begin{array}{c}0.403^{* * *} \\
(4.12)\end{array}$ & $\begin{array}{c}0.419^{* * * 3} \\
(3.99)\end{array}$ & $\begin{array}{c}0.274^{* *} \\
(2.26)\end{array}$ & $\begin{array}{c}0.294^{* *} \\
(2.32)\end{array}$ \\
\hline Fund Pub_Poor & & & $\begin{array}{l}0.122 \\
(1.03)\end{array}$ & $\begin{array}{l}0.176 \\
(1.42)\end{array}$ \\
\hline Fund SemPub_Good & $\begin{array}{c}-0.384^{* * *} \\
(-3.65)\end{array}$ & $\begin{array}{c}-0.416^{* * * *} \\
(-3.84)\end{array}$ & $\begin{array}{l}-0.164 \\
(-1.37)\end{array}$ & $\begin{array}{c}-0.18 \\
(-1.48)\end{array}$ \\
\hline ExpenseRatio & $\begin{array}{c}-0.085^{* * *} \\
(-9.82)\end{array}$ & $\begin{array}{c}-0.087^{* * *} \\
(-9.9)\end{array}$ & $\begin{array}{c}-0.083^{* * * *} \\
(-8.58)\end{array}$ & $\begin{array}{c}-0.082^{* * * *} \\
(-8.28)\end{array}$ \\
\hline Turnover & $\begin{array}{l}-0.019 \\
(-1.18)\end{array}$ & $\begin{array}{l}-0.018 \\
(-1.12)\end{array}$ & $\begin{array}{l}0.014 \\
(0.77)\end{array}$ & $\begin{array}{l}0.016 \\
(0.91)\end{array}$ \\
\hline FundSize & $\begin{array}{c}-0.024^{* * * *} \\
(-8.13)\end{array}$ & $\begin{array}{c}-0.024^{* * *} \\
(-8.05)\end{array}$ & $\begin{array}{c}-0.016^{* * * *} \\
(-5.1)\end{array}$ & $\begin{array}{c}-0.016^{* * *} \\
(-4.88)\end{array}$ \\
\hline Constant & $\begin{array}{c}0.559^{* * *} \\
(8.99)\end{array}$ & $\begin{array}{c}0.570^{* * *} \\
(8.99)\end{array}$ & $\begin{array}{c}0.400^{* * * *} \\
(5.82)\end{array}$ & $\begin{array}{c}0.388^{* * *} \\
(5.56)\end{array}$ \\
\hline Country and Year Fixe & & & & \\
\hline Effects & Yes & Yes & Yes & Yes \\
\hline Observations & 27078 & 26381 & 21631 & 21209 \\
\hline R-square & 0.049 & 0.049 & 0.055 & 0.055 \\
\hline
\end{tabular}




\section{Table 4: Illiquidity and the Use of Semi-public Information}

The table reports the results of the following panel regression:

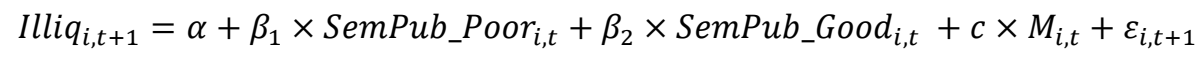

where Illiq $_{i, t+1}$ is the illiquidity of stock $i$, proxied by Amihud Illiquidity and the percentage of zero returns; SemPub_Poor ${ }_{i, t}$ and SemPub_Good ${ }_{i, t}$ are holding-weighted averages of the use of public information by funds that invest in the stock; and the vector of $M_{i, t}$ stacks a list of control variables, including firm-level governance (Firm Gov), the volatility of fund flows (Flow_Std), the level of cash over total asset of firms (Cash/TA), capital expenditures (CAPEX), return on assets (ROA), institutional ownership (IO), the buy-and-hold return during the previous 6 months (MOM), book-to-market (BM), LogSize, and a dummy variable that takes the value of one when Firm Gov is available and zero otherwise. These variables are defined in the Appendix B1 and are lagged by one period. Regression residuals are clustered by country and year. The superscripts ${ }^{* * *},{ }^{* *}$, and ${ }^{*}$ refer to $1 \%$, $5 \%$, and $10 \%$ levels of statistical significance, respectively. The sample includes firm-semiannual observations over the period 2000 to 2009.

\begin{tabular}{|c|c|c|c|c|c|c|c|c|}
\hline & 1 & 2 & 3 & 4 & 5 & 6 & 7 & 8 \\
\hline & \multicolumn{4}{|c|}{ Amihud Illiquidity } & \multicolumn{4}{|c|}{$\begin{array}{l}\text { Zero Return } \\
\end{array}$} \\
\hline & \multicolumn{2}{|c|}{ Horizontal Gov } & \multicolumn{2}{|c|}{ Vertical Gov } & \multicolumn{2}{|c|}{ Horizontal Gov } & \multicolumn{2}{|c|}{ Vertical Gov } \\
\hline SemPub_Poor & $\begin{array}{l}0.336^{* *} \\
(2.54)\end{array}$ & $\begin{array}{l}0.341^{* *} \\
(2.43)\end{array}$ & $\begin{array}{l}0.427^{* * *} \\
(3.82)\end{array}$ & $\begin{array}{l}0.410^{* * *} \\
(3.44)\end{array}$ & $\begin{array}{l}0.089^{* * *} \\
(2.01)\end{array}$ & $\begin{array}{l}0.083^{* *} \\
(2.19)\end{array}$ & $\begin{array}{l}0.072^{* *} \\
(2.21)\end{array}$ & $\begin{array}{l}0.064^{* *} \\
(2.01)\end{array}$ \\
\hline SemPub_Good & $\begin{array}{l}-0.024 \\
(-0.42)\end{array}$ & $\begin{array}{l}-0.025 \\
(-0.47)\end{array}$ & $\begin{array}{l}-0.04 \\
(-0.86)\end{array}$ & $\begin{array}{l}-0.039 \\
(-0.93)\end{array}$ & $\begin{array}{l}-0.062 \\
(-1.4)\end{array}$ & $\begin{array}{l}-0.057 \\
(-1.45)\end{array}$ & $\begin{array}{l}-0.06 \\
(-1.46)\end{array}$ & $\begin{array}{l}-0.055 \\
(-1.51)\end{array}$ \\
\hline Firm Gov & & $\begin{array}{l}-0.063 \\
(-1.37)\end{array}$ & & $\begin{array}{l}-0.063 \\
(-1.36)\end{array}$ & & $\begin{array}{l}-0.131^{*} \\
(-1.65)\end{array}$ & & $\begin{array}{l}-0.131^{*} \\
(-1.65)\end{array}$ \\
\hline Flow_Std & $\begin{array}{l}16.988^{* *} \\
(2.5)\end{array}$ & $\begin{array}{l}17.446^{* *} \\
(2.58)\end{array}$ & $\begin{array}{l}16.930^{* *} \\
(2.49)\end{array}$ & $\begin{array}{l}17.387^{* *} \\
(2.56)\end{array}$ & $\begin{array}{l}0.43 \\
(0.6)\end{array}$ & $\begin{array}{l}0.311 \\
(0.46)\end{array}$ & $\begin{array}{l}0.417 \\
(0.58)\end{array}$ & $\begin{array}{l}0.298 \\
(0.45)\end{array}$ \\
\hline $\mathrm{Cash} / \mathrm{TA}$ & $\begin{array}{l}-1.866 \\
(-1.5)\end{array}$ & $\begin{array}{l}-1.962 \\
(-1.53)\end{array}$ & $\begin{array}{l}-1.86 \\
(-1.48)\end{array}$ & $\begin{array}{l}-1.952 \\
(-1.51)\end{array}$ & $\begin{array}{l}0.45 \\
(0.82)\end{array}$ & $\begin{array}{l}0.676 \\
(1.11)\end{array}$ & $\begin{array}{l}0.457 \\
(0.82)\end{array}$ & $\begin{array}{l}0.683 \\
(1.11)\end{array}$ \\
\hline CapEx & $\begin{array}{l}-5.030^{* * *} \\
(-3.9)\end{array}$ & $\begin{array}{l}-4.890^{* * *} \\
(-3.88)\end{array}$ & $\begin{array}{l}-5.026^{* * *} \\
(-3.91)\end{array}$ & $\begin{array}{l}-4.886^{* * *} \\
(-3.88)\end{array}$ & $\begin{array}{l}-0.405 \\
(-0.74)\end{array}$ & $\begin{array}{l}-0.416 \\
(-0.74)\end{array}$ & $\begin{array}{l}-0.405 \\
(-0.74)\end{array}$ & $\begin{array}{l}-0.416 \\
(-0.74)\end{array}$ \\
\hline ROA & $\begin{array}{l}0.167 \\
(0.78)\end{array}$ & $\begin{array}{l}0.224 \\
(0.97)\end{array}$ & $\begin{array}{l}0.168 \\
(0.78)\end{array}$ & $\begin{array}{l}0.225 \\
(0.97)\end{array}$ & $\begin{array}{l}0.057 \\
(0.4)\end{array}$ & $\begin{array}{l}0.037 \\
(0.28)\end{array}$ & $\begin{array}{l}0.057 \\
(0.4)\end{array}$ & $\begin{array}{l}0.037 \\
(0.28)\end{array}$ \\
\hline IO & $\begin{array}{l}-9.700^{* * *} \\
(-4.35)\end{array}$ & $\begin{array}{l}-8.552^{* * *} \\
(-3.71)\end{array}$ & $\begin{array}{l}-9.740^{* * *} \\
(-4.36)\end{array}$ & $\begin{array}{l}-8.588^{* * *} \\
(-3.71)\end{array}$ & $\begin{array}{l}-0.427 \\
(-1.54)\end{array}$ & $\begin{array}{l}-0.415^{*} \\
(-1.69)\end{array}$ & $\begin{array}{l}-0.427 \\
(-1.53)\end{array}$ & $\begin{array}{l}-0.415^{*} \\
(-1.68)\end{array}$ \\
\hline MOM & $\begin{array}{l}-0.039^{* * *} \\
(-5)\end{array}$ & $\begin{array}{l}-0.038^{* * *} \\
(-5.3)\end{array}$ & $\begin{array}{l}-0.039^{* * *} \\
(-5.01)\end{array}$ & $\begin{array}{l}-0.037^{* * *} \\
(-5.31)\end{array}$ & $\begin{array}{l}-0.007^{* *} \\
(-2.09)\end{array}$ & $\begin{array}{l}-0.006^{*} \\
(-1.96)\end{array}$ & $\begin{array}{l}-0.007^{* *} \\
(-2.08)\end{array}$ & $\begin{array}{l}-0.006^{*} \\
(-1.95)\end{array}$ \\
\hline BM & $\begin{array}{l}1.878^{* * *} \\
(5.81)\end{array}$ & $\begin{array}{l}1.984^{* * *} \\
(4.9)\end{array}$ & $\begin{array}{l}1.873^{\text {**** }} \\
(5.84)\end{array}$ & $\begin{array}{l}1.980^{* * * *} \\
(4.92)\end{array}$ & $\begin{array}{l}-0.292 \\
(-0.75)\end{array}$ & $\begin{array}{l}-0.244 \\
(-0.79)\end{array}$ & $\begin{array}{l}-0.291 \\
(-0.75)\end{array}$ & $\begin{array}{l}-0.243 \\
(-0.79)\end{array}$ \\
\hline LogSize & $\begin{array}{l}0.01 \\
(1.2)\end{array}$ & $\begin{array}{l}0.007 \\
(0.9)\end{array}$ & $\begin{array}{l}0.009 \\
(1.18)\end{array}$ & $\begin{array}{l}0.007 \\
(0.88)\end{array}$ & $\begin{array}{l}-0.011^{*} \\
(-1.93)\end{array}$ & $\begin{array}{l}-0.011^{* *} \\
(-2.13)\end{array}$ & $\begin{array}{l}-0.011^{*} \\
(-1.94)\end{array}$ & $\begin{array}{l}-0.011^{*} \\
(-2.14)\end{array}$ \\
\hline Dummy (Firm Gov) & & $\begin{array}{l}0.097^{* * * *} \\
(4.57)\end{array}$ & & $\begin{array}{l}0.097^{* * *} \\
(4.56)\end{array}$ & & $\begin{array}{l}0.056 \\
(1.57)\end{array}$ & & $\begin{array}{l}0.056 \\
(1.57)\end{array}$ \\
\hline Constant & $\begin{array}{l}-0.309^{*} \\
(-1.77)\end{array}$ & $\begin{array}{l}-0.224 \\
(-1.3)\end{array}$ & $\begin{array}{l}-0.307^{*} \\
(-1.75)\end{array}$ & $\begin{array}{l}-0.222 \\
(-1.29)\end{array}$ & $\begin{array}{l}0.255^{* *} \\
(2.01)\end{array}$ & $\begin{array}{l}0.257^{* * *} \\
(2.23)\end{array}$ & $\begin{array}{l}0.255^{* *} \\
(2.01)\end{array}$ & $\begin{array}{l}0.256^{* *} \\
(2.23)\end{array}$ \\
\hline $\begin{array}{l}\text { Country and Year } \\
\text { Fixed-Effects }\end{array}$ & Yes & Yes & Yes & Yes & Yes & Yes & Yes & Yes \\
\hline Observations & 102773 & 102773 & 102758 & 102758 & 102776 & 102776 & 102761 & 102761 \\
\hline R-square & 0.199 & 0.214 & 0.2 & 0.214 & 0.575 & 0.583 & 0.575 & 0.583 \\
\hline
\end{tabular}


Table 5: Idiosyncratic Volatility and the Use of Semi-public Information

The table reports the results of the following panel regression:

$$
\text { Idio_vol }_{i, t+1}=\alpha+\beta_{1} \times \text { SemPub_Poor }{ }_{i, t}+\beta_{2} \times S_{\text {SemPub_Good }}+c \times M_{i, t}+\varepsilon_{i, t+1}
$$

where $I d i o_{-} v o l_{i, t+1}$ refers to the $\log$ of one plus the Idiosyncratic Volatility of stock $i$ during the period,

$S_{\text {SemPub_Poor }}$ i,t and SemPub_Good ${ }_{i, t}$ are holding-weighted averages of the use of public information by funds that invest in the stock, and the vector of $M_{i, t}$ stacks a list of control variables. These variables are defined in the Appendix B and are lagged by one period. Regression residuals are clustered by country and year. The superscripts ******, and " refer to $1 \%, 5 \%$, and $10 \%$ levels of statistical significance, respectively. The sample includes firmsemiannual observations over the 2000-2009 period.

\begin{tabular}{|c|c|c|c|c|c|c|c|c|}
\hline \multirow[b]{4}{*}{ SemPub_Poor } & 1 & 2 & 3 & 4 & 5 & 6 & 7 & 8 \\
\hline & \multicolumn{4}{|c|}{$\begin{array}{c}\text { Idiosyncratic Volatility From } \\
\text { Domestic and Global Fama-French factors }\end{array}$} & \multicolumn{4}{|c|}{$\begin{array}{l}\text { Idiosyncratic Volatility from } \\
\text { Industry and Market Factors }\end{array}$} \\
\hline & \multicolumn{2}{|c|}{ Horizontal Gov } & \multicolumn{2}{|c|}{ Vertical Gov } & \multicolumn{2}{|c|}{ Horizontal Gov } & \multicolumn{2}{|c|}{ Vertical Gov } \\
\hline & $\begin{array}{l}0.025 * * * \\
(4.94)\end{array}$ & $\begin{array}{l}0.026^{* * * *} \\
(4.99)\end{array}$ & $\begin{array}{l}0.021 * * * \\
(3.91)\end{array}$ & $\begin{array}{l}0.022^{* * * *} \\
(3.84)\end{array}$ & $\begin{array}{l}0.024 * * * \\
(4.16)\end{array}$ & $\begin{array}{l}0.025 * * * \\
(4.28)\end{array}$ & $\begin{array}{l}0.018 * * * \\
(3.52)\end{array}$ & $\begin{array}{l}0.019 * * * \\
(3.48)\end{array}$ \\
\hline SemPub_Good & $\begin{array}{l}0.011 * * * \\
(5.21)\end{array}$ & $\begin{array}{l}0.011^{* * *} * \\
(5.33)\end{array}$ & $\begin{array}{l}0.012 * * * \\
(5.54)\end{array}$ & $\begin{array}{l}0.012 * * * \\
(5.65)\end{array}$ & $\begin{array}{l}0.010 * * * \\
(4.45)\end{array}$ & $\begin{array}{l}0.010 * * * \\
(4.49)\end{array}$ & $\begin{array}{l}0.011 * * * \\
(4.72)\end{array}$ & $\begin{array}{l}0.011 * * * \\
(4.79)\end{array}$ \\
\hline Firm Gov & & $\begin{array}{l}0.009 * * * \\
(4.42)\end{array}$ & & $\begin{array}{l}0.009 * * * \\
(4.42)\end{array}$ & & $\begin{array}{l}0.010 * * * \\
(5.53)\end{array}$ & & $\begin{array}{l}0.010 * * * \\
(5.53)\end{array}$ \\
\hline Flow_Std & $\begin{array}{l}1.941 * * * \\
(4.38)\end{array}$ & $\begin{array}{l}1.833 * * * \\
(3.66)\end{array}$ & $\begin{array}{l}1.932 * * * \\
(4.4)\end{array}$ & $\begin{array}{l}1.824 * * * \\
(3.67)\end{array}$ & $\begin{array}{l}1.775 * * * \\
(4.63)\end{array}$ & $\begin{array}{l}1.682 * * * \\
(4.33)\end{array}$ & $\begin{array}{l}1.762 * * * \\
(4.65)\end{array}$ & $\begin{array}{l}1.669 * * * \\
(4.37)\end{array}$ \\
\hline ICRG Political & $\begin{array}{l}-0.020 * * * \\
(-5.09)\end{array}$ & $\begin{array}{l}-0.018 * * * \\
(-4.99)\end{array}$ & $\begin{array}{l}-0.020 * * * \\
(-5.07)\end{array}$ & $\begin{array}{l}-0.018 * * * \\
(-4.98)\end{array}$ & $\begin{array}{l}-0.019 * * * \\
(-4.73)\end{array}$ & $\begin{array}{l}-0.017 * * * \\
(-4.94)\end{array}$ & $\begin{array}{l}-0.019 * * * \\
(-4.69)\end{array}$ & $\begin{array}{l}-0.017 * * * \\
(-4.9)\end{array}$ \\
\hline Creditor rights & $\begin{array}{l}-0.002 \\
(-1.54)\end{array}$ & $\begin{array}{l}-0.002 \\
(-1.35)\end{array}$ & $\begin{array}{l}-0.002 \\
(-1.54)\end{array}$ & $\begin{array}{l}-0.002 \\
(-1.35)\end{array}$ & $\begin{array}{l}-0.001 \\
(-0.89)\end{array}$ & $\begin{array}{l}-0.001 \\
(-0.76)\end{array}$ & $\begin{array}{l}-0.001 \\
(-0.9)\end{array}$ & $\begin{array}{l}-0.001 \\
(-0.77)\end{array}$ \\
\hline Anti-director rights & $\begin{array}{l}0.031 \\
(0.39)\end{array}$ & $\begin{array}{l}0.041 \\
(0.52)\end{array}$ & $\begin{array}{l}0.03 \\
(0.39)\end{array}$ & $\begin{array}{l}0.041 \\
(0.52)\end{array}$ & $\begin{array}{l}0.078 \\
(1.11)\end{array}$ & $\begin{array}{l}0.088 \\
(1.26)\end{array}$ & $\begin{array}{l}0.077 \\
(1.1)\end{array}$ & $\begin{array}{l}0.088 \\
(1.25)\end{array}$ \\
\hline Stock market turnover & $\begin{array}{l}0.002 \\
(1.04)\end{array}$ & $\begin{array}{l}0.002 \\
(1.06)\end{array}$ & $\begin{array}{l}0.002 \\
(1.04)\end{array}$ & $\begin{array}{l}0.002 \\
(1.07)\end{array}$ & $\begin{array}{l}0.001 \\
(0.66)\end{array}$ & $\begin{array}{l}0.001 \\
(0.66)\end{array}$ & $\begin{array}{l}0.001 \\
(0.67)\end{array}$ & $\begin{array}{l}0.001 \\
(0.66)\end{array}$ \\
\hline Stock market Capit. (\%GDP) & $\begin{array}{l}0.145 * * * \\
(6.07)\end{array}$ & $\begin{array}{l}0.112 \\
(1.32)\end{array}$ & $\begin{array}{l}0.144 * * * \\
(5.9)\end{array}$ & $\begin{array}{l}0.111 \\
(1.3)\end{array}$ & $\begin{array}{l}0.132 * * * \\
(3.7)\end{array}$ & $\begin{array}{l}0.101 \\
(1.21)\end{array}$ & $\begin{array}{l}0.131 * * * \\
(3.71)\end{array}$ & $\begin{array}{l}0.1 \\
(1.19)\end{array}$ \\
\hline Private bond market (\%GDP) & $\begin{array}{l}-0.002 * \\
(-1.95)\end{array}$ & $\begin{array}{l}-0.002 * \\
(-1.73)\end{array}$ & $\begin{array}{l}-0.002^{*} \\
(-1.95)\end{array}$ & $\begin{array}{l}-0.002 * \\
(-1.73)\end{array}$ & $\begin{array}{l}-0.003 * * \\
(-2.34)\end{array}$ & $\begin{array}{l}-0.003 * * \\
(-2.14)\end{array}$ & $\begin{array}{l}-0.003 * * \\
(-2.35)\end{array}$ & $\begin{array}{l}-0.003 * * \\
(-2.15)\end{array}$ \\
\hline Equity market liberalization & $\begin{array}{l}-0.002 \\
(-0.52)\end{array}$ & $\begin{array}{l}-0.003 \\
(-0.65)\end{array}$ & $\begin{array}{l}-0.002 \\
(-0.47)\end{array}$ & $\begin{array}{l}-0.002 \\
(-0.6)\end{array}$ & $\begin{array}{l}-0.004 \\
(-1.15)\end{array}$ & $\begin{array}{l}-0.005 \\
(-1.26)\end{array}$ & $\begin{array}{l}-0.004 \\
(-1.1)\end{array}$ & $\begin{array}{l}-0.005 \\
(-1.21)\end{array}$ \\
\hline Disclosure & $\begin{array}{l}0.001 \\
(0.5)\end{array}$ & $\begin{array}{l}0.001 \\
(0.62)\end{array}$ & $\begin{array}{l}0.001 \\
(0.49)\end{array}$ & $\begin{array}{l}0.001 \\
(0.61)\end{array}$ & $\begin{array}{l}0.002 * * \\
(1.98)\end{array}$ & $\begin{array}{l}0.002 * * \\
(2.09)\end{array}$ & $\begin{array}{l}0.002 * * \\
(1.96)\end{array}$ & $\begin{array}{l}0.002 * * \\
(2.08)\end{array}$ \\
\hline $\mathrm{PPE} / \mathrm{TA}$ & $\begin{array}{l}-0.001 * * \\
(-2.52)\end{array}$ & $\begin{array}{l}-0.001 * * \\
(-2.35)\end{array}$ & $\begin{array}{l}-0.001 * * \\
(-2.51)\end{array}$ & $\begin{array}{l}-0.001 * * \\
(-2.33)\end{array}$ & $\begin{array}{l}-0.002 * * * \\
(-4.18)\end{array}$ & $\begin{array}{l}-0.002 * * * \\
(-4.04)\end{array}$ & $\begin{array}{l}-0.002 * * * \\
(-4.19)\end{array}$ & $\begin{array}{l}-0.002 \text { *** } \\
(-4.06)\end{array}$ \\
\hline ROA & $\begin{array}{l}-0.072 \\
(-1.44)\end{array}$ & $\begin{array}{l}-0.071 \\
(-1.42)\end{array}$ & $\begin{array}{l}-0.072 \\
(-1.44)\end{array}$ & $\begin{array}{l}-0.071 \\
(-1.42)\end{array}$ & $\begin{array}{l}-0.083 \\
(-1.42)\end{array}$ & $\begin{array}{l}-0.082 \\
(-1.4)\end{array}$ & $\begin{array}{l}-0.084 \\
(-1.42)\end{array}$ & $\begin{array}{l}-0.082 \\
(-1.4)\end{array}$ \\
\hline Cash/TA & $\begin{array}{l}0.006^{* * * *} \\
(2.95)\end{array}$ & $\begin{array}{l}0.006 \text { *** } \\
(2.93)\end{array}$ & $\begin{array}{l}0.006^{* * * *} \\
(2.95)\end{array}$ & $\begin{array}{l}0.006^{* * * *} \\
(2.93)\end{array}$ & $\begin{array}{l}0.006^{* * * *} \\
(2.63)\end{array}$ & $\begin{array}{l}0.006 * * * \\
(2.62)\end{array}$ & $\begin{array}{l}0.006^{* * * *} \\
(2.63)\end{array}$ & $\begin{array}{l}0.006^{* * * *} \\
(2.62)\end{array}$ \\
\hline Debt maturity & $\begin{array}{l}0.022 \\
(0.52)\end{array}$ & $\begin{array}{l}0.025 \\
(0.59)\end{array}$ & $\begin{array}{l}0.022 \\
(0.52)\end{array}$ & $\begin{array}{l}0.025 \\
(0.59)\end{array}$ & $\begin{array}{l}-0.011 \\
(-0.31)\end{array}$ & $\begin{array}{l}-0.007 \\
(-0.22)\end{array}$ & $\begin{array}{l}-0.01 \\
(-0.3)\end{array}$ & $\begin{array}{l}-0.007 \\
(-0.21)\end{array}$ \\
\hline$R \& D$ & $\begin{array}{l}0.015 * * * \\
(5.08)\end{array}$ & $\begin{array}{l}0.014 * * * \\
(5.17)\end{array}$ & $\begin{array}{l}0.015 * * * \\
(5.1)\end{array}$ & $\begin{array}{l}0.014 \text { *** } \\
(5.19)\end{array}$ & $\begin{array}{l}0.020 \text { *** } \\
(6.75)\end{array}$ & $\begin{array}{l}0.020 * * * \\
(6.81)\end{array}$ & $\begin{array}{l}0.020 * * * * \\
(6.78)\end{array}$ & $\begin{array}{l}0.020 * * * \\
(6.84)\end{array}$ \\
\hline Zero Return & $\begin{array}{l}0.037 \\
(0.08)\end{array}$ & $\begin{array}{l}0.147 \\
(0.33)\end{array}$ & $\begin{array}{l}0.038 \\
(0.08)\end{array}$ & $\begin{array}{l}0.148 \\
(0.34)\end{array}$ & $\begin{array}{l}0.118 \\
(0.27)\end{array}$ & $\begin{array}{l}0.24 \\
(0.58)\end{array}$ & $\begin{array}{l}0.119 \\
(0.28)\end{array}$ & $\begin{array}{l}0.241 \\
(0.58)\end{array}$ \\
\hline Age $(\log )$ & $\begin{array}{l}-0.001 * * * \\
(-3.05)\end{array}$ & $\begin{array}{l}-0.001 * * * \\
(-3.15)\end{array}$ & $\begin{array}{l}-0.001 * * * \\
(-3.07)\end{array}$ & $\begin{array}{l}-0.001 * * * \\
(-3.17)\end{array}$ & $\begin{array}{l}-0.001 * * * \\
(-2.59)\end{array}$ & $\begin{array}{l}-0.001 * * * \\
(-2.71)\end{array}$ & $\begin{array}{l}-0.001 * * * \\
(-2.61)\end{array}$ & $\begin{array}{l}-0.001 * * * \\
(-2.73)\end{array}$ \\
\hline Leverage & $\begin{array}{l}0.075 * * * \\
(2.71)\end{array}$ & $\begin{array}{l}0.074 * * * \\
(2.67)\end{array}$ & $\begin{array}{l}0.075 * * * \\
(2.72)\end{array}$ & $\begin{array}{l}0.073 * * * \\
(2.67)\end{array}$ & $\begin{array}{l}0.072 * * * \\
(2.59)\end{array}$ & $\begin{array}{l}0.071 * * \\
(2.56)\end{array}$ & $\begin{array}{l}0.072 * * * \\
(2.59)\end{array}$ & $\begin{array}{l}0.071^{* *} \\
(2.56)\end{array}$ \\
\hline IO & $\begin{array}{l}-0.048 \\
(-1.08)\end{array}$ & $\begin{array}{l}-0.02 \\
(-0.89)\end{array}$ & $\begin{array}{l}-0.048 \\
(-1.07)\end{array}$ & $\begin{array}{l}-0.019 \\
(-0.86)\end{array}$ & $\begin{array}{l}-0.127 * * * \\
(-4.95)\end{array}$ & $\begin{array}{l}-0.098 * * \\
(-2.24)\end{array}$ & $\begin{array}{l}-0.126 * * * \\
(-4.96)\end{array}$ & $\begin{array}{l}-0.098 * * \\
(-2.23)\end{array}$ \\
\hline $\mathrm{BM}$ & $\begin{array}{l}2.677 \\
(0.64)\end{array}$ & $\begin{array}{l}2.609 \\
(0.62)\end{array}$ & $\begin{array}{l}2.673 \\
(0.64)\end{array}$ & $\begin{array}{l}2.606 \\
(0.62)\end{array}$ & $\begin{array}{l}2.955 \\
(0.74)\end{array}$ & $\begin{array}{l}2.86 \\
(0.71)\end{array}$ & $\begin{array}{l}2.95 \\
(0.74)\end{array}$ & $\begin{array}{l}2.855 \\
(0.71)\end{array}$ \\
\hline LogSize & $\begin{array}{l}-0.002 * * * \\
(-5.58)\end{array}$ & $\begin{array}{l}-0.002 * * * \\
(-6.32)\end{array}$ & $\begin{array}{l}-0.002 * * * \\
(-5.57)\end{array}$ & $\begin{array}{l}-0.002 * * * \\
(-6.3)\end{array}$ & $\begin{array}{l}-0.003 * * * \\
(-6.57)\end{array}$ & $\begin{array}{l}-0.003 * * * \\
(-7.59)\end{array}$ & $\begin{array}{l}-0.003 * * * \\
(-6.59)\end{array}$ & $\begin{array}{l}-0.003 * * * \\
(-7.61)\end{array}$ \\
\hline Dummy (Firm Gov) & & $\begin{array}{l}-0.005 * * * \\
(-3.79)\end{array}$ & & $\begin{array}{l}-0.005 * * * \\
(-3.8)\end{array}$ & & $\begin{array}{l}-0.005 * * * \\
(-4.42)\end{array}$ & & $\begin{array}{l}-0.005 * * * \\
(-4.43)\end{array}$ \\
\hline Constant & $\begin{array}{l}0.078 * * * \\
(6.66)\end{array}$ & $\begin{array}{l}0.077 * * * * \\
(6.82)\end{array}$ & $\begin{array}{l}0.078 \text { *** } \\
(6.65)\end{array}$ & $\begin{array}{l}0.077 * * * \\
(6.82)\end{array}$ & $\begin{array}{l}0.087 \text { *** } \\
(7.3)\end{array}$ & $\begin{array}{l}0.087 * * * \\
(7.51)\end{array}$ & $\begin{array}{l}0.087 * * * \\
(7.28)\end{array}$ & $\begin{array}{l}0.087 * * * \\
(7.49)\end{array}$ \\
\hline Year Fixed-Effects & Yes & Yes & Yes & Yes & & & & \\
\hline Observations & 81793 & 81793 & 81779 & 81779 & 81793 & 81793 & 81779 & 81779 \\
\hline R-square & 0.436 & 0.44 & 0.436 & 0.44 & 0.434 & 0.438 & 0.434 & 0.438 \\
\hline
\end{tabular}




\section{Table 6: Firm Value and the Use of Semi-public Information}

Panel A reports the results of the following panel regression:

$$
\text { Ret }_{i, t+1}=\alpha+\beta_{1 g} \times \text { SemPub_Poor }_{i, t} \times D_{\text {Good }}+\beta_{1 b} \times \text { SemPub_Poor }_{i, t} \times D_{\text {bad }}+\beta_{2 g} \times \text { SemPub_Good }_{i, t} \times D_{G o o d}+\beta_{2 b}
$$

$\times$ SemPub_Good $_{i, t} \times D_{\text {bad }}+c \times M_{i, t}+\varepsilon_{i, t+1}$

where Ret $_{i, t+1}$ refers to the raw return of stock $i$ in columns 1-4 and its DGTW return in columns 5-8, $D_{\text {good }}$ and $D_{b a d}$ are dummies referring to positive and negative changes in standardized analyst recommendations, SemPub_Poor ${ }_{i, t}$ and SemPub_Good Sem $_{i, t}$ are holding-weighted averages of the use of public information by funds that invest in the stock, and the vector of $M_{i, t}$ stacks control variables defined in Appendix B. In Panel B, the dependent variables are log market-to-book ratios and log Tobin's Q. The residuals are clustered by country and year. The superscripts ${ }^{* * *},{ }^{* *}$, and ${ }^{*}$ refer to $1 \%, 5 \%$, and $10 \%$ levels of statistical significance, respectively. We include firm-semiannual observations over the 2000-2009 period.

\begin{tabular}{|c|c|c|c|c|c|c|c|c|}
\hline & 1 & 2 & 3 & 4 & 5 & 6 & 7 & 8 \\
\hline \multicolumn{9}{|c|}{ Panel A. Stock Performance and SemPub_Poor with Information Dummy } \\
\hline & \multicolumn{4}{|c|}{ Raw Return } & \multicolumn{4}{|c|}{ DGTW return } \\
\hline & \multicolumn{2}{|c|}{ Horizontal Gov } & \multicolumn{2}{|c|}{ Vertical Gov } & \multicolumn{2}{|c|}{ Horizontal Gov } & \multicolumn{2}{|c|}{ Vertical Gov } \\
\hline SemPub_Poor* Dgood & $\begin{array}{l}0.150^{* * *} \\
(5.08)\end{array}$ & $\begin{array}{l}0.149^{* * *} \\
(5.12)\end{array}$ & $\begin{array}{l}0.087^{* * *} \\
(3.31)\end{array}$ & $\begin{array}{l}0.085^{* * *} \\
(3.16)\end{array}$ & $\begin{array}{l}0.131^{\text {**** }} \\
(5.26)\end{array}$ & $\begin{array}{l}0.13^{* * *} \\
(5.38)\end{array}$ & $\begin{array}{l}0.094^{* * *} \\
(4.92)\end{array}$ & $\begin{array}{l}0.093^{* * *} \\
(5.07)\end{array}$ \\
\hline SemPub_Poor*Dbad & $\begin{array}{l}-0.11^{* * *} \\
(-2.77)\end{array}$ & $\begin{array}{l}-0.109^{* * *} \\
(-2.77)\end{array}$ & $\begin{array}{l}-0.141^{* * *} \\
(-2.71)\end{array}$ & $\begin{array}{l}-0.142^{* * *} \\
(-2.69)\end{array}$ & $\begin{array}{l}-0.101^{\text {*** }} \\
(-4.09)\end{array}$ & $\begin{array}{l}-0.101^{\text {*** }} \\
(-4.11)\end{array}$ & $\begin{array}{l}-0.115^{* * *} \\
(-4.26)\end{array}$ & $\begin{array}{l}-0.115^{\text {*** }} \\
(-4.24)\end{array}$ \\
\hline SemPub_Good*Dgood & $\begin{array}{l}0.023 \\
(0.79)\end{array}$ & $\begin{array}{l}0.022 \\
(0.76)\end{array}$ & $\begin{array}{l}0.0341 \\
(1.28)\end{array}$ & $\begin{array}{l}0.033 \\
(1.23)\end{array}$ & $\begin{array}{l}0.053^{* * * *} \\
(2.94)\end{array}$ & $\begin{array}{l}0.0529^{* * *} \\
(2.94)\end{array}$ & $\begin{array}{l}0.0604^{* * *} \\
(3.48)\end{array}$ & $\begin{array}{l}0.06^{* * *} \\
(3.49)\end{array}$ \\
\hline SemPub_Good *Dbad & $\begin{array}{l}-0.068^{* * * *} \\
(-3.15)\end{array}$ & $\begin{array}{l}-0.0679^{* * * *} \\
(-3.18)\end{array}$ & $\begin{array}{l}-0.0658^{* * *} \\
(-3.21)\end{array}$ & $\begin{array}{l}-0.066^{* * *} \\
(-3.25)\end{array}$ & $\begin{array}{l}-0.031^{* * *} \\
(-2.92)\end{array}$ & $\begin{array}{l}-0.0315^{* * * *} \\
(-2.96)\end{array}$ & $\begin{array}{l}-0.0312^{* * *} \\
(-2.71)\end{array}$ & $\begin{array}{l}-0.031^{* * * *} \\
(-2.75)\end{array}$ \\
\hline Firm Gov & & $\begin{array}{l}-0.002 \\
(-0.39)\end{array}$ & & $\begin{array}{l}-0.002 \\
(-0.39)\end{array}$ & & $\begin{array}{l}-0.0025 \\
(-0.45)\end{array}$ & & $\begin{array}{l}-0.003 \\
(-0.44)\end{array}$ \\
\hline Flow_Std & $\begin{array}{l}-2.3517 \\
(-0.7)\end{array}$ & $\begin{array}{l}-2.2778 \\
(-0.68)\end{array}$ & $\begin{array}{l}-2.3497 \\
(-0.7)\end{array}$ & $\begin{array}{l}-2.275 \\
(-0.68)\end{array}$ & $\begin{array}{l}-0.916 \\
(-0.8)\end{array}$ & $\begin{array}{l}-0.8785 \\
(-0.75)\end{array}$ & $\begin{array}{l}-0.8948 \\
(-0.78)\end{array}$ & $\begin{array}{l}-0.857 \\
(-0.74)\end{array}$ \\
\hline MOM & $\begin{array}{l}-0.001 \\
(-0.32)\end{array}$ & $\begin{array}{l}-0.001 \\
(-0.25)\end{array}$ & $\begin{array}{l}-0.001 \\
(-0.33)\end{array}$ & $\begin{array}{l}-0.001 \\
(-0.26)\end{array}$ & $\begin{array}{l}-0.001 \\
(-0.66)\end{array}$ & $\begin{array}{l}-0.001 \\
(-0.6)\end{array}$ & $\begin{array}{l}-0.001 \\
(-0.66)\end{array}$ & $\begin{array}{l}-0.001 \\
(-0.61)\end{array}$ \\
\hline leverage & $\begin{array}{l}-0.758 \\
(-1.08)\end{array}$ & $\begin{array}{l}-0.753 \\
(-1.07)\end{array}$ & $\begin{array}{l}-0.758 \\
(-1.08)\end{array}$ & $\begin{array}{l}-0.753 \\
(-1.07)\end{array}$ & $\begin{array}{l}-0.219^{* *} \\
(-2.25)\end{array}$ & $\begin{array}{l}-0.216^{* *} \\
(-2.24)\end{array}$ & $\begin{array}{l}-0.219^{* *} \\
(-2.25)\end{array}$ & $\begin{array}{l}-0.216^{* *} \\
(-2.24)\end{array}$ \\
\hline IO & $\begin{array}{l}-0.419 \\
(-1.06)\end{array}$ & $\begin{array}{l}-0.363 \\
(-0.94)\end{array}$ & $\begin{array}{l}-0.409 \\
(-1.02)\end{array}$ & $\begin{array}{l}-0.351 \\
(-0.91)\end{array}$ & $\begin{array}{l}-0.326^{* * *} \\
(-5.72)\end{array}$ & $\begin{array}{l}-0.293^{* * *} \\
(-4.66)\end{array}$ & $\begin{array}{l}-0.326^{* * *} \\
(-5.72)\end{array}$ & $\begin{array}{l}-0.287^{* * * *} \\
(-4.64)\end{array}$ \\
\hline BM & $\begin{array}{l}0.024 \\
(0.56)\end{array}$ & $\begin{array}{l}0.038 \\
(0.81)\end{array}$ & $\begin{array}{l}0.030 \\
(0.68)\end{array}$ & $\begin{array}{l}0.043 \\
(0.92)\end{array}$ & $\begin{array}{l}-0.286^{* * *} \\
(-7.37)\end{array}$ & $\begin{array}{l}-0.277^{* * *} \\
(-8.53)\end{array}$ & $\begin{array}{l}-0.286^{* * *} \\
(-7.37)\end{array}$ & $\begin{array}{l}-0.273^{* * * *} \\
(-8.43)\end{array}$ \\
\hline LogSize & $\begin{array}{l}-0.003^{* * *} \\
(-2.71)\end{array}$ & $\begin{array}{l}-0.003^{* * *} \\
(-2.73)\end{array}$ & $\begin{array}{l}-0.003^{* * *} \\
(-2.65)\end{array}$ & $\begin{array}{l}-0.003^{* * *} \\
(-2.67)\end{array}$ & $\begin{array}{l}-0.001^{* * *} \\
(-2.69)\end{array}$ & $\begin{array}{l}-0.001^{* *} \\
(-2.52)\end{array}$ & $\begin{array}{l}-0.001^{* * *} \\
(-2.69)\end{array}$ & $\begin{array}{l}-0.001^{* * *} \\
(-2.44)\end{array}$ \\
\hline Dummy (Firm Gov) & & $\begin{array}{l}0.0044 \\
(1.15)_{* * *}\end{array}$ & & $\begin{array}{l}0.004 \\
(1.15)_{* * *}\end{array}$ & & $\begin{array}{l}0.003 \\
(0.87)\end{array}$ & & $\begin{array}{l}0.003 \\
(0.87)\end{array}$ \\
\hline Constant & $\begin{array}{l}0.117^{* * * *} \\
(5.7)\end{array}$ & $\begin{array}{l}0.121^{* * * *} \\
(5.43)\end{array}$ & $\begin{array}{l}0.117^{* * *} \\
(5.65)\end{array}$ & $\begin{array}{l}0.120^{* * *} \\
(5.4)\end{array}$ & $\begin{array}{l}0.023^{* * * *} \\
(2.69)\end{array}$ & $\begin{array}{l}0.025^{* *} \\
(2.43)\end{array}$ & $\begin{array}{l}0.0228^{* * *} \\
(2.63)\end{array}$ & $\begin{array}{l}0.0249^{* *} \\
(2.39)\end{array}$ \\
\hline $\begin{array}{l}\text { Country and Year } \\
\text { Fixed-Effects }\end{array}$ & Yes & Yes & Yes & Yes & Yes & Yes & Yes & Yes \\
\hline Observations & 96103 & 96091 & 96103 & 96091 & 96103 & 96103 & 96091 & 96091 \\
\hline R-square & 0.224 & 0.224 & 0.224 & 0.224 & 0.018 & 0.02 & 0.017 & 0.02 \\
\hline \multicolumn{9}{|c|}{ Panel B: Firm value and SemPub_Poor } \\
\hline & \multicolumn{4}{|c|}{ Market to Book } & \multicolumn{4}{|c|}{ Tobin's Q } \\
\hline & \multicolumn{2}{|c|}{ Horizontal Gov } & \multicolumn{2}{|c|}{ Vertical Gov } & \multicolumn{2}{|c|}{ Horizontal Gov } & \multicolumn{2}{|c|}{ Vertical Gov } \\
\hline SemPub_Poor & $\begin{array}{c}-0.363 * * * \\
(-3.16)\end{array}$ & $\begin{array}{c}-0.255^{* *} \\
(-2.23)\end{array}$ & $\begin{array}{c}-0.399 * * * \\
(-3.59)\end{array}$ & $\begin{array}{c}-0.267 * * \\
(-2.41)\end{array}$ & $\begin{array}{c}-0.237 * * * \\
(-2.72)\end{array}$ & $\begin{array}{c}-0.160^{*} \\
(-1.83)\end{array}$ & $\begin{array}{c}-0.258 * * * \\
(-3.06)\end{array}$ & $\begin{array}{c}-0.164^{*} \\
(-1.95)\end{array}$ \\
\hline SemPub_Good & $\begin{array}{c}0.152 * * * \\
(3.01)\end{array}$ & $\begin{array}{c}0.152 * * * \\
(3.02)\end{array}$ & $\begin{array}{c}0.158 * * * \\
\quad(3.11)\end{array}$ & $\begin{array}{c}0.157 * * * \\
(3.10)\end{array}$ & $\begin{array}{c}0.101 * * * \\
(2.62)\end{array}$ & $\begin{array}{c}0.101 * * * \\
(2.63)\end{array}$ & $\begin{array}{c}0.106 * * * \\
(2.75)\end{array}$ & $\begin{array}{c}0.105 * * * \\
(2.73)\end{array}$ \\
\hline Firm Gov & & $\begin{array}{l}0.122 * * * \\
(5.97)\end{array}$ & & $\begin{array}{l}0.122 * * * \\
(5.96)\end{array}$ & & $\begin{array}{c}0.098 * * * \\
(6.34)\end{array}$ & & $\begin{array}{c}0.098 * * * \\
(6.33)\end{array}$ \\
\hline Flow_Std & $\begin{array}{c}-65.157 * * * \\
(-7.02)\end{array}$ & $\begin{array}{c}-56.721 * * * * \\
(-6.13)\end{array}$ & $\begin{array}{c}-65.293 * * * \\
(-7.03)\end{array}$ & $\begin{array}{c}-56.818 * * * \\
(-6.14)\end{array}$ & $\begin{array}{c}-43.376 * * * \\
(-6.16)\end{array}$ & $\begin{array}{c}-37.436 \text { **** } \\
(-5.33)\end{array}$ & $\begin{array}{c}-43.458 * * * \\
(-6.17)\end{array}$ & $\begin{array}{c}-37.490 * * * \\
(-5.33)\end{array}$ \\
\hline LogSize & $\begin{array}{c}0.170 * * * \\
(68.29)\end{array}$ & $\begin{array}{l}0.172 * * * \\
(69.25)\end{array}$ & $\begin{array}{c}0.170 * * * \\
(68.29)\end{array}$ & $\begin{array}{c}0.172 * * * \\
(69.24)\end{array}$ & $\begin{array}{c}0.131^{* * *} * \\
(69.44)\end{array}$ & $\begin{array}{c}0.133 * * * \\
(70.29)\end{array}$ & $\begin{array}{c}0.131 * * * \\
(69.45)\end{array}$ & $\begin{array}{c}0.133 * * * \\
(70.28)\end{array}$ \\
\hline$R \& D$ & $\begin{array}{c}0.164 * * * \\
(3.88)\end{array}$ & $\begin{array}{c}0.174 * * * \\
(4.13)\end{array}$ & $\begin{array}{c}0.163 * * * \\
(3.87)\end{array}$ & $\begin{array}{c}0.174 * * * \\
(4.13)\end{array}$ & $\begin{array}{c}0.416^{* * * *} \\
(12.99)\end{array}$ & $\begin{array}{c}0.423 * * * \\
(13.24)\end{array}$ & $\begin{array}{c}0.416 * * * \\
(12.99)\end{array}$ & $\begin{array}{c}0.423 * * * \\
(13.24)\end{array}$ \\
\hline ROE & $\begin{array}{c}0.038 * * \\
(2.31)\end{array}$ & $\begin{array}{c}0.037 * * \\
(2.24)\end{array}$ & $\begin{array}{c}0.038 * * \\
(2.30)\end{array}$ & $\begin{array}{c}0.037 * * \\
(2.24)\end{array}$ & $\begin{array}{c}0.085^{* * * *} \\
\quad(6.69)\end{array}$ & $\begin{array}{c}0.084 * * * \\
(6.64)\end{array}$ & $\begin{array}{c}0.085 * * * \\
\quad(6.69)\end{array}$ & $\begin{array}{c}0.084 * * * \\
\quad(6.64)\end{array}$ \\
\hline FROE & $\begin{array}{c}0.010 * * * \\
(3.32)\end{array}$ & $\begin{array}{l}0.010^{* * *} \\
(3.28)\end{array}$ & $\begin{array}{c}0.010 * * * \\
(3.34)\end{array}$ & $\begin{array}{c}0.010 * * * \\
(3.30)\end{array}$ & $\begin{array}{l}0.003 \\
(1.19)\end{array}$ & $\begin{array}{l}0.003 \\
(1.15)\end{array}$ & $\begin{array}{l}0.003 \\
(1.20)\end{array}$ & $\begin{array}{l}0.003 \\
(1.16)\end{array}$ \\
\hline F2ROE & $\begin{array}{c}-0.006^{* *} \\
(-2.26)\end{array}$ & $\begin{array}{c}-0.006^{* *} \\
(-2.32)\end{array}$ & $\begin{array}{c}-0.006^{* *} \\
(-2.28)\end{array}$ & $\begin{array}{c}-0.006 * * \\
(-2.33)\end{array}$ & $\begin{array}{l}-0.001 \\
(-0.72)\end{array}$ & $\begin{array}{l}-0.001 \\
(-0.77)\end{array}$ & $\begin{array}{l}-0.001 \\
(-0.74)\end{array}$ & $\begin{array}{l}-0.001 \\
(-0.78)\end{array}$ \\
\hline Dummy (Firm Gov) & & $\begin{array}{c}-0.151^{* * * *} \\
(-15.40)\end{array}$ & & $\begin{array}{c}-0.151^{* * * *} \\
(-15.36)\end{array}$ & & $\begin{array}{c}-0.110 * * * \\
(-14.81)\end{array}$ & & $\begin{array}{c}-0.110 * * * \\
(-14.78)\end{array}$ \\
\hline Constant & $\begin{array}{c}-3.323^{* * * *} \\
(-64.34)\end{array}$ & $\begin{array}{c}-3.337 * * * \\
(-64.83)\end{array}$ & $\begin{array}{c}-3.323 * * * \\
(-64.35)\end{array}$ & $\begin{array}{c}-3.338 * * * \\
(-64.83)\end{array}$ & $\begin{array}{c}-2.541 * * * \\
(-64.85)\end{array}$ & $\begin{array}{c}-2.550 * * * \\
(-65.25)\end{array}$ & $\begin{array}{c}-2.541^{* * * *} \\
(-64.86)\end{array}$ & $\begin{array}{c}-2.550 * * * \\
(-65.26)\end{array}$ \\
\hline $\begin{array}{l}\text { Firm and Year } \\
\text { Fixed-Effects }\end{array}$ & Yes & Yes & Yes & Yes & Yes & Yes & Yes & Yes \\
\hline Observations & 90,545 & 90,545 & 90,533 & 90,533 & 90,545 & 90,545 & 90,533 & 90,533 \\
\hline R-square & 0.814 & 0.815 & 0.814 & 0.815 & 0.832 & 0.833 & 0.832 & 0.833 \\
\hline
\end{tabular}




\section{Table 7: Crisis Period Liquidity Crunches}

The table reports the results of the following cross-sectional regression with country fixed effects:

$$
\text { Illiq }_{i}=\alpha+\beta_{1} \times \text { SemPub_Poor }{ }_{i}+\beta_{2} \times \text { SemPub_Good }_{i}+c \times M_{i}+\varepsilon_{i}
$$

where $\Delta$ Illiq is the illiquidity (proxied by Amihud Illiquidity and Zero Return) of stock $i$ during the crisis period (2008-2009) minus that of the pre-crisis period (2005-2007),SemPub_Poor ${ }_{i}$ and SemPub_Good $i$ are holdingweighted averages of the use of semi-public information by funds in the pre-crisis period for the stock, and the vector of $M_{i}$ stacks a list of control variables as defined in Appendix B. All control variables are computed as the mean of their pre-crisis period values. The superscripts ${ }^{* * * *},{ }^{* * *}$, and ${ }^{*}$ refer to $1 \%, 5 \%$, and $10 \%$ levels of statistical significance, respectively.

\begin{tabular}{|c|c|c|c|c|}
\hline & 1 & 2 & 3 & 4 \\
\hline & \multicolumn{2}{|c|}{$\Delta$ Amihud Illiquidity } & \multicolumn{2}{|c|}{$\Delta$ Zero Return } \\
\hline & Horizontal Gov & Vertical Gov & Horizontal Gov & Vertical Gov \\
\hline \multirow[t]{2}{*}{ SemPub_Poor } & $1.008^{* * *}$ & $0.921^{* * *}$ & $0.112^{* * *}$ & $0.128^{* * * *}$ \\
\hline & $(3.62)$ & $(3.45)$ & $(2.96)$ & $(3.57)$ \\
\hline \multirow[t]{2}{*}{ SemPub_Good } & $-0.619^{* * *}$ & $-0.613^{* * *}$ & 0.006 & 0.003 \\
\hline & $(-5.06)$ & $(-5)$ & $(0.37)$ & $(0.16)$ \\
\hline \multirow[t]{2}{*}{ Flow_Std } & -6.074 & -6.188 & 1.474 & 1.492 \\
\hline & $(-0.63)$ & $(-0.64)$ & $(1.18)$ & (1.19) \\
\hline \multirow[t]{2}{*}{ Cash/TA } & $-3.781^{* * * *}$ & $-3.794^{* * * *}$ & $0.189^{*}$ & $0.185^{*}$ \\
\hline & $(-4.76)$ & $(-4.78)$ & $(1.83)$ & $(1.79)$ \\
\hline \multirow[t]{2}{*}{ CapEx } & 0.047 & 0.043 & 0.012 & 0.011 \\
\hline & $(0.12)$ & $(0.11)$ & $(0.23)$ & $(0.23)$ \\
\hline \multirow[t]{2}{*}{ ROA } & 0.219 & 0.221 & -0.075 & -0.074 \\
\hline & $(0.54)$ & $(0.55)$ & $(-1.43)$ & $(-1.43)$ \\
\hline \multirow[t]{2}{*}{ IO } & $6.358^{* * * *}$ & $6.345^{* * *}$ & $-0.356^{* * * *}$ & $-0.366^{* * * *}$ \\
\hline & $(9.13)$ & (9.09) & $(-3.7)$ & $(-3.81)$ \\
\hline \multirow[t]{2}{*}{ MOM } & $-0.033^{* * *}$ & $-0.033^{* * *}$ & $-0.005^{* * *}$ & $-0.005^{* * *}$ \\
\hline & $(-6.98)$ & $(-6.98)$ & $(-7.44)$ & $(-7.44)$ \\
\hline \multirow[t]{2}{*}{$\mathrm{BM}$} & $-6.836^{* * * *}$ & $-6.787^{* * * *}$ & 0.075 & 0.079 \\
\hline & $(-3.62)$ & $(-3.6)$ & $(0.31)$ & $(0.32)$ \\
\hline \multirow[t]{2}{*}{ LogSize } & $-0.048^{* * *}$ & $-0.049^{* * *}$ & $-0.002^{* * *}$ & $-0.002^{* * * *}$ \\
\hline & $(-38.5)$ & $(-38.38)$ & $(-10.38)$ & $(-10.53)$ \\
\hline \multirow[t]{2}{*}{ Constant } & $1.070^{* * * *}$ & $1.071^{* * * *}$ & $0.036^{* * *}$ & $0.036^{* * *}$ \\
\hline & $(40.37)$ & $(40.27)$ & $(8.65)$ & $(8.76)$ \\
\hline Country Fixed-Effects & Yes & Yes & Yes & Yes \\
\hline Observations & 8265 & 8265 & 8265 & 8265 \\
\hline R-square & 0.264 & 0.264 & 0.149 & 0.15 \\
\hline
\end{tabular}




\section{Table 8: Crisis Period Return and Pre-Crisis SemPub_Poor}

The table reports the results of the following cross-sectional regression:

$$
\Delta V_{i}=\alpha+\beta_{1} \times \text { SemPub_Poor }_{i}+\beta_{2} \times \text { SemPub_Good }_{i}+c \times M_{i}+\varepsilon_{i}
$$

where $\Delta V_{\mathrm{i}}$ is the change in value of stock $i$, proxied by the DGTW return of stock $i$ during the 2008-2009 crisis period in columns 1 and 2 and the increment of market-to-book ratios from the pre-crisis period to the crisis period in in columns 3 and 4. SemPub_Poor ${ }_{i}$ and SemPub_Good $i$ are holding-weighted average of the use of semi-public information by funds in the pre-crisis period for the stock, the vector of $M_{i}$ stacks a list of control variables as defined in Appendix B. All control variables are computed as the mean of their pre-crisis period values. The superscripts ${ }^{* * *}, * *$, and ${ }^{*}$ refer to $1 \%, 5 \%$, and $10 \%$ levels of statistical significance, respectively.

\begin{tabular}{|c|c|c|c|c|}
\hline & 1 & 2 & 3 & 4 \\
\hline & \multicolumn{2}{|c|}{ DGTW Return } & \multicolumn{2}{|c|}{$\Delta$ Market to Book } \\
\hline & Horizontal Gov & Vertical Gov & Horizontal Gov & Vertical Gov \\
\hline SemPub_Poor & $\begin{array}{c}-0.217^{* * * *} \\
(-4.16)\end{array}$ & $\begin{array}{c}-0.17^{* * * *} \\
(-3.41)\end{array}$ & $\begin{array}{l}-2.835 * * * \\
(-4)\end{array}$ & $\begin{array}{l}-2.231 * * * * \\
(-3.33)\end{array}$ \\
\hline SemPub_Good & $\begin{array}{l}0.032 \\
(1.42)\end{array}$ & $\begin{array}{l}0.026 \\
(1.15)\end{array}$ & $\begin{array}{l}-0.011 \\
(-0.04)\end{array}$ & $\begin{array}{l}-0.092 \\
(-0.3)\end{array}$ \\
\hline Flow_Std & $\begin{array}{l}-2.326 \\
(-0.96)\end{array}$ & $\begin{array}{l}-2.239 \\
(-0.92)\end{array}$ & $\begin{array}{l}-15.323 \\
(-0.43)\end{array}$ & $\begin{array}{l}-13.979 \\
(-0.4)\end{array}$ \\
\hline Leverage & $\begin{array}{l}-0.883^{* * * *} \\
(-4.25)\end{array}$ & $\begin{array}{c}-0.883^{* * * *} \\
(-4.25)\end{array}$ & & \\
\hline IO & $\begin{array}{l}-0.773^{* * *} \\
(-6.44)\end{array}$ & $\begin{array}{c}-0.777^{* * * *} \\
(-6.46)\end{array}$ & & \\
\hline MOM & $\begin{array}{l}0.017^{* * * *} \\
(20.38)\end{array}$ & $\begin{array}{l}0.017^{* * * *} \\
(20.38)\end{array}$ & & \\
\hline BM & $\begin{array}{l}0.128 \\
(0.4)\end{array}$ & $\begin{array}{l}0.126 \\
(0.39)\end{array}$ & & \\
\hline LogSize & $\begin{array}{c}0.001^{* * *} \\
(2.21)\end{array}$ & $\begin{array}{c}0.001^{* * *} \\
(2.14)\end{array}$ & $\begin{array}{l}0.033 * * * \\
(11.75)\end{array}$ & $\begin{array}{l}0.032 * * * \\
(11.61)\end{array}$ \\
\hline $\mathrm{R} \& \mathrm{D}$ & & & $\begin{array}{l}0.723 * * * \\
(8.75)\end{array}$ & $\begin{array}{l}0.722 * * * \\
(8.74)\end{array}$ \\
\hline ROE & & & $\begin{array}{l}-0.640 * * * \\
(-7.47)\end{array}$ & $\begin{array}{l}-0.636 * * * \\
(-7.43)\end{array}$ \\
\hline Constant & $\begin{array}{c}-0.03^{* * *} \\
(-5.86)\end{array}$ & $\begin{array}{c}-0.03^{* * *} \\
(-5.75)\end{array}$ & $\begin{array}{l}-1.093 * * * \\
(-19.28)\end{array}$ & $\begin{array}{l}-1.089 * * * \\
(-19.18)\end{array}$ \\
\hline Country Fixed-Effects & Yes & Yes & Yes & Yes \\
\hline Observations & 7826 & 7826 & 7756 & 7756 \\
\hline R-square & 0.06 & 0.06 & 0.033 & 0.033 \\
\hline
\end{tabular}




\section{Table 9: Endogeneity Test}

The table reports the results of the following two panel regressions:

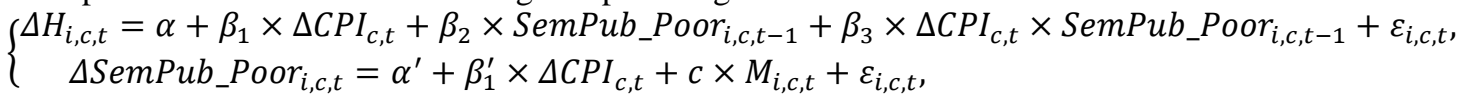

where $\Delta H_{i, c, t}$ is the percentage change in the aggregate mutual fund holdings of stock $i$ with the level of SemPub_Poor ${ }_{i, c, t-1}$ in country $c$ (in which the stock is traded) over the period of $t, \Delta S_{\text {SemiPub_Poor }}$ i,c,t is the change in the value of SemPub_Poor of the stock over period $t$ conditioned on the fund ownership information observed at $t-1$, and $\triangle C P I_{c, t}$ is the annual change in the Corruption Perceptions Index of country $c$, in which stock $i$ is traded. The Corruption Perceptions Index ranges from 0 (very clean) to 10 (highly corrupt). $M_{i, c, t}$ stacks a list of control variables. The superscripts ${ }^{* * *},{ }^{* *}$, and ${ }^{*}$ refer to $1 \%, 5 \%$, and $10 \%$ levels of statistical significance, respectively. The sample includes firm-year observations over the 2000-2009 period.

\begin{tabular}{|c|c|c|c|c|}
\hline \multirow[b]{3}{*}{ Parameter } & \multirow{2}{*}{\multicolumn{2}{|c|}{$\begin{array}{lr}1 & 2 \\
\text { Dependent variable }=\Delta H_{i, C, t}\end{array}$}} & 3 & 4 \\
\hline & & & \multicolumn{2}{|c|}{ Dependent variable $=\Delta$ SemPub_Poor ${ }_{i, C, t}$} \\
\hline & Horizontal Gov & Vertical Gov & Horizontal Gov & Vertical Gov \\
\hline$\Delta \mathrm{CPI}$ & $\begin{array}{c}0.01 \\
(079)\end{array}$ & $\begin{array}{l}-0.004 \\
(-0.34)\end{array}$ & $0.11^{* *}$ & $0.15^{* * *}$ \\
\hline SemPub_Poor ${ }_{i, t-1-1}$ & $\begin{array}{c}-0.526^{* * *} \\
(-4)\end{array}$ & $\begin{array}{c}-0.455 * * * \\
(-3.73)\end{array}$ & $(2.4+)$ & \\
\hline$\Delta \mathrm{CPI} *$ SemPub_Poor ${ }_{\mathrm{i}, \mathrm{c}, \mathrm{t}-\mathrm{1}}$ & $\begin{array}{c}-1.066^{* *} \\
(2.15)\end{array}$ & $\begin{array}{l}0.538 \\
(1.15)\end{array}$ & & \\
\hline IO & $\begin{array}{l}-5.495^{* * *} \\
(-5.5)\end{array}$ & $\begin{array}{l}-5.453 * * * \\
(-5.45)\end{array}$ & $\begin{array}{l}4.698 \\
-1.17\end{array}$ & $\begin{array}{l}0.497 \\
-0.12\end{array}$ \\
\hline MOM & $\begin{array}{l}0.108^{* * * *} \\
(17.04)\end{array}$ & $\begin{array}{c}0.108 * * * \\
(17.03)\end{array}$ & $\begin{array}{l}0.027 \\
-0.94\end{array}$ & $\begin{array}{c}0.024 \\
-0.8\end{array}$ \\
\hline BM & $\begin{array}{l}1.976^{*} \\
(1.73)\end{array}$ & $\begin{array}{l}1.967^{*} \\
(1.72)\end{array}$ & $\begin{array}{l}0.068 \\
-0.02\end{array}$ & $\begin{array}{l}3.341 \\
-0.78\end{array}$ \\
\hline Logsize & $\begin{array}{l}0.008^{* * *} \\
(4.47)\end{array}$ & $\begin{array}{c}0.009 * * * \\
(4.53)\end{array}$ & $\begin{array}{l}0.012 \\
-1.59\end{array}$ & $\begin{array}{l}0.004 \\
-0.53\end{array}$ \\
\hline Constant & $\begin{array}{l}-0.039 \\
(-0.79)\end{array}$ & $\begin{array}{l}-0.042 \\
(-0.84)\end{array}$ & $\begin{array}{l}-0.358^{*} \\
(-1.81)\end{array}$ & $\begin{array}{l}-0.208 \\
(-0.99)\end{array}$ \\
\hline Observations & 56142 & 56142 & 51066 & 51066 \\
\hline R-square & 0.047 & 0.047 & 0.006 & 0.005 \\
\hline
\end{tabular}

